\title{
ADMINISTRACIÓN DE JUSTICIA Y JUSTICIA ADMINISTRATIVA EN LA CONSTITUCIÓN DE 1869
}

\author{
RAFAEL DE MENDIZÁBAL ALLENDE \\ Magistrado del Tribunal Constitucional \\ Presidente de Sala del Supremo, Emérito \\ Académico Numerario de la Real Academia de Jurisprudencia \\ y Legislación \\ Abogado del llustre Colegio de Abogados de Madrid
}




\section{SUMARIO}

I. El mARCo hISTórico. 1. De la "Vicalvarada" a la "Gloriosa». 2. La Administración pública y el ordenamiento jurídico. 3. Administración de Justicia y Poder Judicial. 4. Los hombres de toga. II. Lo CONTENCIOSO-ADM!NISTRATIVo. 1. Nacimiento y configuración. 2. La Revolución de 1868. 3. La Ley Orgánica del Poder Judicial. 3.1. Finalidad de la reforma. 3.2. Subsistencia de los contencioso-administrativo. Su naturaleza problemática. 3.3. Judicialización. 3.4. Consecuencias procesales. 3.4.1. Representación y defensa de los litigantes. 3.4.2. Incidente previo acerca de la admisibilidad de la demanda. 3.4.3. La actividad probatoria. 3.4.4. La resolución definitiva. 3.5. Conclusión. III. EL TRIBUNAL DE CUENTAS. 1. Características de la Ley Orgánica. 2. Delimitación jurisdiccional. IV. EPILOGO: LA JUSTICIA CONSTITUCIONAL A LA VISTA. 


\title{
ADMINISTRACIÓN DE JUSTICIA Y JUSTICIA ADMINISTRATIVA EN LA CONSTITUCIÓN DE 1869
}

POR

\author{
RAFAEL DE MENDIZÁBAL ALLENDE \\ Magistrado del Tribunal Constitucional \\ Presidente de Sala del Supremo, Emérito \\ Académico Numerario de la Real Academia de Jurisprudencia \\ y Legislación \\ Abogado del Ilustre Colegio de Abogados de Madrid
}

\section{EL MARCO HISTÓRICO}

\section{De la "Vicalvarada» a la "Gloriosa"}

La "década moderada» es un período social y económicamente complejo, en un clima de cierta rigidez política, que oscila entre lo bochornoso y lo pintoresco. Dentro de su inmovilismo se produjeron, sin embargo, planteamientos certeros, cuya fecundidad pudo haber sido mayor en circunstancias distintas y con hombres diferentes. Como quedó bosquejado en su lugar oportuno, se ponen en esta época los cimientos de una Administración pública de perfil contemporáneo, cuyas directrices se inspiran en el modelo francés. En la periferia (Cataluña y el País Vasco) surge un pujante espíritu de empresa que pone en marcha la incipiente industrialización, mientras que en el centro de la Península este capitalismo balbuciente asume un carácter financiero y especulador, en franca complicidad con el Poder público. La ineficacia de la recién estrenada organización administrativa, carente de un equipo humano honesto y técnicamente preparado, se potencia por 
la inmoralidad de los personajes políticos prominentes, los "prohombres» en el retórico lenguaje de la época 1 .

Contra este ambiente de corrupción, el único en el que, según parece, nuestra burguesía decimonónica podía respirar satisfecha, se produce el pronunciamiento militar conocido por la "Vicalvarada". Una coalición de "progresistas" y "moderados", encabezada por los generales Espartero, O'Donnell, Narváez y Serrano, enemigos del "abogado" que pretendió implantar la supremacía del poder civil (Bravo Murillo), triunfa en 1854, después de unas escaramuzas de resuitado indeciso y como consecuencia del apoyo popular, que la habilidad política de Cánovas del Castillo supo atraer mediante el "Manifiesto de Manzanares». Con la entrada de Espartero en Madrid el 29 de julio se inicia el llamado "bienio progresista", regido por un "consulado" que forman el Duque de la Victoria y O'Donnell. Derogada la Constitución de 1845, se elabora otra nueva en 1856 que no liegó a promulgarse.

Este movimiento revolucionario, claro antecedente del que se produciría en 1868, recibe el apoyo, todavía débil, del partido «democrático" que, con cierta tendencia republicana, se había desgajado de la extrema izquierda del progresismo en 1847, bajo la inspiración de Nicolás María Rivero; en las Cortes de 1851 hizo sus primeras armas parlamentarias, con una plana mayor constituida por el fundador, Albaida, y Estanislao Figueras. Frente a este grupo, aparece en las elecciones de 1854 la "Unión Liberal", integrada por la izquierda del partido moderado y los progresistas templados, bajo la jefatura de O'Donnell; su apogeo lo alcanzará en 1858. Bajo esta superficie burguesa se agita el "cuarto estado" y surgen los primeros conflictos sociales en el año 1855 en las ciudades más populosas (Barcelona, Zaragoza, Valencia, Burgos, Valladolid, etc.).

El "consulado" que preside el "bienio progresista" se deshace mediante una maniobra de O'Donnell, en complicidad con Isabel II. Así, el 14 de julio de 1856 es eliminado del poder el general Espartero y su forzada dimisión origina una protesta armada del progresismo y una

1 Martin Retortillo, Sebastián, Aguas públicas y obras hidráulicas, Madrid, 1966, pág. 25, alude explícitamente a «la intolerancia, el dogmatismo, el orgullo, la corrupción y espíritu de secta...". No cabe en menos palabras un más certero diagnóstico de la década moderada, cuya amoralidad política subraya también Aranguren, José Luis L., Moral y Sociedad ( Introducción a la moral social española del siglo $X(X)$ ), Madrid, 1965, págs. 101 a 103. 
situación claramente revolucionaria, en la que la propia víctima del golpe de Estado se abstuvo de intervenir. Existe un evidente paralelismo entre esta coyuntura histórica y la de 1843, aun cuando con ligeras variaciones. Su efecto más ostensible consistió en separar definitivamente a la burguesía liberal y al proletariado, que hasta entonces habian luchado juntos. Por otra parte, el partido progresista ya no tendrá la oportunidad de gobernar y se retraerá definitivamente de toda actividad legal en 1863, al ser privado del derecho de reunión para la propaganda electoral, pasando así a la clandestinidad y la acción directa. Se restablece la Constitución de 1845, con un Acta adicional de la que es autor Ríos Rosas (RD de 15 de septiembre).

En los doce años siguientes se aprecia una gradual inestabilidad política, cuyo reflejo ostensible es la sucesión de gobiernos de efímera duración. Ya el 12 de octubre, despechado por un desaire público de la Reina, se ve obligado a dimitir el general O'Donnell, al que sucede en la Presidencia del Consejo el general Narváez; suspendida la desamortización, se deroga toda la legislación del bienio, se anula el Acta adicional mediante el RD de 14 de octubre y se modifica la Constitución de 1845 por la Ley de 17 de julio de 1857, obra de Cándido Nocedal. Este mismo año nace el Príncipe Alfonso. Armero reemplaza un año después a Narváez y es, a su vez, sustituido por Istúriz, que pocos meses después deja paso nuevamente a O'Donnell y la "Unión Liberal» (30 de junio de 1858); durante los cinco años de su mandato se plantean numerosos conflictos sociales, estalla la guerra con Marruecos, la República de Santo Domingo solicita espontáneamente su anexión a España y se envía una expedición militar a Méjico, que manda Prim. Diversas crisis del Gabinete se resuelven meditante sucesivas reorganizaciones, sin que ello pueda impedir su caída definitiva.

El 2 de marzo de 1863 es nombrado Presidente del Consejo el Marqués de Miraflores, para dejar paso el 16 de enero de 1864 al Gobierno formado por Arrazola, que enseguida tendrá que ceder el puesto al hacendista Mon. Éste deroga la reforma constitucional de 1857 por medio de la Ley de 20 de abril de 1864. El mismo año se constituye un nuevo Gabinete bajo la jefatura de Narváez, y al siguiente aparece en escena otra vez $O^{\prime}$ Donnell, que es sustituido el 10 de julio de 1867 por su rival. Ambos desáparecen de la escena política y de este gran teatro del mundo con un intervalo de pocos meses, entre diciembre de 1867 y abril de 1868. Ocupa entonces la presidencia del Consejo González Bravo, el personaje más corrompido del país.

Mientras tanto, diversos movimientos revolucionarios han ido minando el subsuelo del sistema. Un alzamiento republicano en Oli- 
venza (1859), otro socialista en Loja (1860), el motín de la noche de San Daniel, como consecuencia de la protesta por la destitución de Castelar de su cátedra (1865), una sublevación de Prim, otra de los sargentos del Cuartel de San Gil (1866) y un alzamiento de progresistas y moderados (1867).

Diversas reuniones en el extranjero culminan en el pacto de Ostende, el 16 de agosto de 1866, en el que participan progresistas y demócratas, bajo la jefatura de Prim y al que se adhieren no sólo Serrano, sino incluso los Duques de Montpensier, hermanos de la Reina. Tal hostilidad, planteada desde todos los frentes contra el Trono, estallará con carácter definitivo e irrevocable el 18 de septiembre de 1868 en la bahía de Cádiz, cuando, por orden de Prim, los 21 cañonazos de la fragata "Zaragoza" anuncian el destronamiento de Isabel II. González Bravo dimite inmediatamente y es sustituido por José Gutiérrez de la Concha. Derrotadas en Alcolea las tropas gubernamentales el 28 de septiembre, dos días después la Reina cruza la frontera francesa hacia el destierro. El 3 de octubre entra en Madrid el duque de la Torre, ministro universal, y constituye un Gobierno provisional, convertido en "Poder ejecutivo" el 2 de febrero del año siguiente.

La Revolución de septiembre de 1868, la "Gloriosa", abre un periodo de permanente inestabilidad, con el paso fugaz de diversos regímenes políticos, reflejo de una profunda crisis en la estructura económica y social del país. Es también uno de los sucesos más complejos de nuestra historia política del siglo XIX. Las elecciones para las Cortes Constituyentes ofrecen en 1869 un resultado que prefigura las de 1931; la Asamblea, cuyas sesiones se inauguraron el 11 de febrero, pudo contemplar la apología de la República unitaria y de la federal e incluso la propuesta de que la Nación se gobernara «por sí misma" mediante un Poder ejecutivo compuesto de cinco individuos designados por las Cortes para un período de tres años ${ }^{2}$. Sin embargo, prevalece la solución monárquica, aunque antidinástica, y la Constitución aprobada el 6 de julio de 1869 instaura una Monarquía democrática, enraizada en el principio de soberania nacional que se instrumenta mediante el sufragio universal. Se trata de una "República coronada" que dará paso, sin dificultad alguna, a la auténtica República cuatro años después.

2 Beneyto Pérez, Juan, Historia de la Administración española e Hispanoamericana, Madrid, 1958, pág. 510. MARTINEz CuADRADO, Miguel, "La elección general para las Cortes Constituyentes de 1869", Revista de Estudios Políticos, 1963; también, La revolución de 1868, Madrid, 1968. 
El 16 de junio las Cortes Constituyentes nombran Regente al general Serrano, y éste, a su vez, encomienda la jefatura del Gobierno al general Prim, el hombre de la Revolución y una de las personalidades políticas más sugestivas de nuestro siglo XIX por su rectitud, valor y firmeza de convicciones. Como toda Monarquía necesita un Rey para encarnarse, comienza la búsqueda del candidato entre las familias reinantes europeas, una vez que el general Espartero, mito revolucionario y mero fantasma de si mismo, renuncia a la posibilidad de cambiar su huerta de Logroño por el palacio de la plaza de Oriente. Algunas incidencias de esta operación política a escala internacional servirán como pretexto para el estallido de la guerra franco-prusiana de 1870, que acabará con el segundo Imperio francés y catalizará la unidad alemana, coincidente con la de Italia bajo el cetro de los Saboya. Uno de éstos, Amadeo, duque de Aosta, tras no pocas dudas y vacilaciones, acepta la Corona que se le ofrece $y$ es elegido Rey de España en la sesión parlamentaria del 16 de noviembre. Su entrada en Madrid el 2 de enero de 1871 aparece cargada de fúnebres presagios: tres días antes ha muerto don Juan Prim y con él desaparece el más sólido puntal del Trono. Sólo su indudable talento, su extraordinaria capacidad política (demostrada en Puerto Rico, en Méjico y en tantas otras ocasiones), su experiencia y su prestigio hubieran podido conseguir el arraigo de la nueva dinastía ${ }^{3}$.

Hay mucho de shakespeariano en el drama de Amadeo de Saboya, "este heroico jefe de Estado nómada" 4 , que a mediodía del 11 de febrero de 1873, sin haber cumplido un trienio en el Trono, renuncia a la Corona de España con un mensaje al Congreso patético por lúcido. La respuesta del Congreso a vuelta de correo hace saber que aceptan

3 Para el relato del acontecer histórico transcrito en el texto, se han utilizado fundamentalmente, además de las ya citadas, las siguientes fuentes: BALLESTERos y BeRETTA, A., y BALLESTERos-Gaibrols, A., Historia de España y su influencia en la Historia universal, vols. X, XI y XII, 2. ${ }^{a}$ ed., Barcelona, 1956; MARX, Karl, y ENGELS, Friedrich, Revolución en España. Traducción, prólogo y notas por Manuel Sacristán, 2. ${ }^{a}$ ed., corregida, Barcelona, 1960; PALACIO ATARD, Vicente, Manual de Historia Universal, Espasa Calpe, Madrid, 1960; PIRENNE, Jacques, Historia Universal ("Las grandes corrientes de la Historia»), vol. VI, "El siglo XIX, progresivo y colonialista», 4. ${ }^{a}$ ed., Barcelona, 1963; SÁNCHEZ AGESTA, Luis, Derecho constitucional comparado, 2. ${ }^{a}$ ed., Editora Nacional, Madrid, 1965, como también Historia del constitucionalismo español, 2. ${ }^{\circ}$ ed., IEP, Madrid, 1964; TUÑón DE LARA, Manuel, La España del siglo XIX, París, 1961; VICENS VIVES, Historia de España y América, vol. V, Barcelona, 1961; Zabala Y Lera, Pio, Historia de España, Edad Contemporánea, vols. I y II, Barcelona, 1930.

4 Fernández Almagro, Melchor, Historia política de la España contemporánea, 1868-1885, Alianza Editorial, Madrid, 1968, pág. 131. 
la abdicación y asumen "en si el Poder supremo y la soberanía de la Nación". Es el anuncio del golpe de Estado parlamentario que vendrá a continuación. En sesión conjunta del Congreso y del Senado, prohibida por la Constitución, olvidando que ésta encomendaba el gobierno al Consejo de Ministros en ausencia del Rey, quien, por otra parte, necesitaba de una ley especial para hacer válida su abdicación, esa misma tarde la sedicente y sediciosa Asamblea Nacional proclama la República $^{5}$ y nombra, con carácter interino, un Poder ejecutivo, para cuya presidencia resulta elegido don Estanislao Figueras, que dimite y se exilia unos meses después, sucediéndole $\mathrm{Pi}$ y Margall ${ }^{6}$, cuya renuncia se produce semanas más tarde, la víspera de que se lea el proyecto de Constitución en las Cortes, de cuya presidencia pasa Salmerón a la del Poder ejecutivo, hasta que el 6 de septiembre dimite por no firmar el "cúmplase" de dos sentencias de muerte. Toma entonces posesión el cuarto y último Presidente, Castelar, cuya "República posible» no lo fue. Así, el 3 de enero de 1874, el Capitán General de Madrid, Pavía, ocupa militarmente la Villa y Corte y hace desalojar por la fuerza las Cortes Constituyentes, sin quebrar formalmente la continuidad de la República, cuya presidencia se encomienda al general Serrano ${ }^{7}$. La nueva etapa durará aún menos que la anterior por acentuar el proceso de descomposición y la inestabilidad permanente. La guerra carlista en el Norte, la guerra de Cuba en Ultramar, la proclamación del «Estado catalán", la indisciplina militar, la inseguridad en la calle y el alzamiento cantonal consiguieron hacer realidad no ya la anarquía, sino el caos ${ }^{8}$.

\section{La Administración Pública y el ordenamiento jurídico}

La estructura de la Administración central sufre escasas modificaciones en este largo y reptante período; en cambio, la organizana, 1973.

5 Descola, Jean, Historia de España, 3. ${ }^{\text {a }}$ ed., Editorial Juventud, Barcelo-

6 Hennessy, C. A. M., La República Federal en España («Pi y Margall y el Movimiento Republicano Federal", 1868-74), Madrid, 1966.

7 Materialmente también durará un año más, ese de 1874 , y esa segunda etapa republicana "representó, sin embargo, una excepcional alternativa de encauzamiento de la vida política nacional, dictada por el repliegue hacia posibles posiciones conservadoras de la basta burguesía radical", en opinión de Miguel MARTINEZ CUADRADO, "La burguesía conservadora (1874-1931)", Historia de España, Alfaguara, VI, Alianza Editorial, Madrid, 1973, pág. 7.

8 El "sexenio-pesadilla" lo llama Ricardo DE LA CIERVA, Historia Total de España, Editorial Fénix, Madrid, 1. ${ }^{a}$ ed., 1997, 6. ${ }^{a}$ ed., 1998, pág. 665. 
ción de las Corporaciones locales es el caballo de batalla de los distintos partidos políticos: los progresistas implantan el 5 de julio de 1856 una nueva Ley municipal, que derogan inmediatamente los "unionistas" y es restablecida en todo su vigor por Decreto de 21 de octubre de 1868. En el aspecto funcional, se observa un aumento creciente de la intervención del Estado, no obstante el liberalismo económico, mediante la técnica de las concesiones; debe resaltarse la construcción de la infraestructura ferroviaria, iniciada en 1848 con la línea Barcelona-Mataró, y la promoción de las «obras públicas» ${ }^{9}$. La actividad legislativa en los doce años de gobierno de la Unión Liberal es parca y mediocre. Sólo cabe citar la Ley de 28 de enero de 1856, primera ordenación bancaria, que creó el Banco de España, absorbiendo al de San Fernando, con el que se había fusionado en 1847 el de Isabel II, establecido mediante RD de 25 de enero de 1844; también son dignas de mención las Leyes de instrucción pública $(9$ de septiembre de 1857), la hipotecaria (8 de febrero de 1861) y la del Notariado (28 de mayo de 1862). En materia financiera el impuesto de consumos polariza también las discrepancias partidistas: suprimido en 1854, restablecido después, desaparece nuevamente en 1868; diversas figuras tributarias surgen en esta época: el impuesto minero (1858), otros sobre viajeros de ferrocarril (1864) y las caballerías y carruajes de lujo (1867-1868), así como el de las cédulas de empadronamiento $(1870)^{10}$.

En la primera etapa de la Revolución de 1868 se produce una honda transformación jurídica: entre los meses de abril y octubre de 1870 son elaboradas una serie de leyes que permitirán la perduración sustancial de muchos principios revolucionarios aún después de tamizados por la Restauración. Son normas que regulan aspectos trascendentales de la realidad jurídica en múltiples manifestaciones: el orden público (23 de abril), el Registro y el matrimonio civiles, los recursos de casación, criminal y civil y su procedimiento (17 y 18 de junio), la Contabilidad pública y el Tribunal de Cuentas ( 25 de junio), la extranjería, la abolición de la esclavitud (4 de julio); la carrera diplomática y la consular (24 de julio), el sistema electoral y el régimen jurídico de

9 Martín Retortillo, Sebastián, «Presupuestos constitucionales de la función administrativa en el Derecho positivo español", Revista de Administración Pública, n. ${ }^{\circ} 26$, págs. 11-49.

10 Sobre el principio de la legalidad tributaria y el de la aprobación del presupuesto en los textos constitucionales de la época, SAINZ DE BUJANDA, Fernando, Hacienda y Derecho, I, IEP, Madrid, 1955, págs. 329-330. 
municipios y provincias (20 de agosto), el Código Penal (30 de agosto), el Poder judicial (15 de septiembre) y el Registro de la Propiedad (29 de octubre). De ellas, siete fueron promulgadas con carácter provisional, que por una paradoja frecuente en nuestro país les proporcionó una tremenda resistencia frente a la habitual volubilidad legislativa: la de Contabilidad rigió hasta 1911, la del Tribunal de Cuentas hasta 1924 y luego durante el período 1930-1934, el Código Penal hasta 1928, la Ley de Orden Público hasta 1933, la del Registro Civil hasta 1957 y la Orgánica del Poder Judicial hasta 1985, con 115 años a sus espaldas ${ }^{11}$.

Esta declaración no vuelve a formularse explícitamente en ningún texto constitucional posterior y sólo es recogida de modo implícito al establecerse en 1837, 1845 y 1856 el carácter "exclusivo" de la potestad judicial. Una Ley de Bases de 11 de abril de 1868, en las postrimerías del período isabelino, había autorizado al Gobierno para elaborar una Ley completa y definitiva de ordenación judicial y competencia de los Tribunales del fuero común, asi como para introducir mientras tanto las reformas más urgentes. Entre éstas se incluyeron expresamente la supresión de los fueros de guerra, marina y extranjería en lo respectivo a los negocios civiles (salvo la prevención de los juicios de testamentaría y abintestato) y también la extinción de los Juzgados especiales de Hacienda y Tribunales de Comercio, devolviéndose el conocimiento de todos estos asuntos al fuero común o jurisdicción real y ordinaria (art. $2 .^{\circ}, 1 .^{\mathrm{a}}$ y $2 .^{\circ}$ ).

\section{Administración de Justicia y Poder Judicial}

La Administración de Justicia conserva hasta 1868 las mismas características orgánicas y procesales, según la configuración recibida en 1834, salvo leves retoques que no afectan al conjunto. En el aspecto estructural se perfecciona el estatuto del personal judicial, con una irreversible y clara tendencia hacia su profesionalización, tanto técnica como corporativa; aparecen también ciertos órganos internos (presidencias de sala, juntas gubernativas) y es perfilada la posición del Ministerio Fiscal. En el aspecto funcional aparece el año 1853 la

11 Cfr. Las reformas legislativas del Ministerio de Gracia y Justicia, con notas y observaciones, por D. M. F. M., abogado del llustre Colegio de Madrid, Madrid, 1870, Imprenta de J. A. García, Corredera Baja de San Pablo, 27 (3 pesetas, en Madrid, y 3,50, en provincias). 
"Instrucción" del Magistrado don José de Castro, Marqués de Gerona, derogada poco después, y en 1855 cristaliza la primera codificación del procedimiento civil ${ }^{12}$.

En tal aspecto, conviene aludir a la notoria tensión dialéctica existente entre estos dos conceptos a lo largo del siglo XIX, que reflejan los distintos textos constitucionales en una esgrima verbal. Si el Estatuto de Bayona hablaba del "orden judicial", con una terminología claramente afrancesada, la Constitución de Cádiz se refiere a "los tribunales" y a "la administración de justicia en lo civil y en lo criminal», aun cuando esta actividad se califique como "potestad" y también como "función" ${ }^{13}$. El "poder judicial» hace su primera aparición en la Constitución progresista de 1837 que, sin embargo, no utilizaba las denominaciones simétricas para los órganos legislativos y ejecutivos $^{14}$. En cambio, la carta política «moderada» de 1845 encuadra las instituciones judiciales dentro de la "administración de justicia". La Constitución no promulgada de 1856 insistía en la calificación de "poder", expresión que retorna en 1869 y se consolidará durante un siglo por obra y gracia de la Ley Orgánica, no obstante la sucesión de sistemas políticos muy diversos, cuyas leyes fundamentales coinci-

12 Carretero Pérez, Adolfo: "Introducción a la organización judicial, la organización judicial en 1808", "La Administración de Justicia desde 1808 a 1833 ..., desde 1833 a $1868 \ldots$, desde 1868 a 1898", "Configuración jurídica de la función judicial en la Ley Orgánica», publicados todos ellos en la Revista de Derecho Judicial, números 19 (págs. 121 y ss.), 20 (págs. 143 y ss.), 21 (págs. 169 y ss.), 22 y 24 (págs. 117 y ss. y 121 y ss.), 26 (págs. 83 y ss. y 129 y ss.) y 27 (págs. 120 y ss.), respectivamente; MENDIZÁBAL AlLENDE, Rafael: "Origen y significado del Partido Judicial» y "Renacimiento y arraigo de la demarcación judicial», Boletín de Información del Ministerio de Justicia, números 700, 725 y 726, págs. 3-16, 3-9 y 3-17, respectivamente, así como Función política y proceso histórico de la demarcación judicial, en prensa; PRIETO CASTRO, Leonardo: Trabajos y orientaciones de Derecho procesal, Madrid, 1964, págs. 869 y ss. y 887 y ss.

13 En el párrafo XXXVI del discurso se habla de Administración de Justicia y en el LXIII de ésta y de la potestad judicial, a la que alude el artículo 242 del texto, mientras que el 243 se refiere a las funciones judiciales.

14 Tampoco lo hacía la de $1812 \mathrm{ni}$ las posteriores. El proyecto de Constitución federal de la República española, presentado a las Cortes Constituyentes el 17 de julio de 1873, es el primer texto político español en el que se declara explícitamente que el poder de la Federación se divide en poder legislativo y poder ejecutivo, poder judicial y poder de relación entre estos poderes (art. 45). El otro será el anteproyecto de constitución de la Monarquía española, presentado a la Asamblea Nacional el 6 de julio de 1929, donde se mencionan los tres poderes clásicos, con una función moderadora y de armonía de todos los poderes, encomendada al Rey (art. 43). 
dieron en prescindir de aquella denominación ${ }^{15}$. Muchos de nosotros desearíamos que perdurase por razones estrictamente sentimentales (las razones que sólo el corazón comprende), vaciada ya de su originario significado y revestida de la serena nobleza que le proporciona el transcurso del tiempo.

En una nueva fase, dentro de esta natural evolución, se promulga con carácter provisional el mismo día de la apertura de los Tribunales del año 1870 la Ley Orgánica del Poder Judicial, único texto hasta ahora en el que se ordenan con un criterio integrador, homogéneo y sistemático la estructura y las funciones de la justicia española ${ }^{16}$. Este carácter de auténtico corpus ha sido señalado en alguna ocasión, pero sin advertir su significado. En efecto, la reducción a una coherente unidad de la pluralidad anárquica de normas que regulaban el ejercicio de la potestad judicial se encuentra dentro del ambiente codificador de la época. Sin embargo, bajo esta superficie de simple técnica legislativa, aparentemente inocua, late la intención política de conseguir la unidad social mediante la igualdad jurídica. En el ámbito judicial tal tendencia aprovecha y fomenta la fuerza expansiva del fuero común o real y aspira a la absorción por él de los fueros privilegiados. Resulta así que la unificación formal, normativa, se constituye en el soporte técnico de la unificación jurisdiccional y que ésta, a su vez, sirve de fundamento a la transmutación efectiva de la simple Administración de Justicia en Poder judicial.

La Ley Orgánica del Poder Judicial responde a un doble criterio político, propio del contexto histórico en el que se plantea. Por una parte, tiene su raíz más profunda en el liberalismo, uno de cuyos dogmas

15 La Constitución de 1876 vuelve de nuevo a la Administración de Justicia. En nuestro siglo el anteproyecto de 1929 utiliza la expresión "poder judicial». La carta política de la Segunda República, en 1931, utiliza el rótulo «justicia», aunque en el discurso pronunciado ante las Cortes por el Presidente de la Comisión redactora del proyecto se hable con reiteración del poder judicial y se aluda también en el texto a la Administración de Justicia (art. 95). "La Justicia" es el nombre que recibe en la Ley Orgánica del Estado de 1967.

16 Hasta entonces la organización judicial se encontraba dispersa en innumerables normas, entre las cuales destacaban, aparte de las que establecieron el Tribunal Supremo, las Audiencias y la demarcación judicial, el Reglamento provisional para la Administración de Justicia en lo respectivo a la real jurisdicción ordinaria de 26 de septiembre de 1835, el del Tribunal Supremo de 17 de octubre y las ordenanzas para todas las Audiencias de la Península e islas adyacentes de 19 de diciembre, el Reglamento de los Juzgados de Primera Instancia de 1 de mayo de 1844 y el relativo al Ministerio Fiscal de 9 de abril de 1858. 
es la división de los poderes, dentro de una concepción mecanicista que arranca de Newton en las ciencias físicas y recoge Adam Smith en la economía. La existencia de distintas funciones es algo que exige la mera racionalización del trabajo, pero la separación de poderes va más allá en sus propósitos y ofrece un fundamento psicológico: todo hombre investido de autoridad tiende a abusar de ella, observación que pone de manifiesto empíricamente la "dimensión demoníaca" del poder, a la que aludía San Agustín. En esta línea, Montesquieu añade a la distribución cuantitativa, un ingrediente cualitativo: la limitación del poder por el poder, mediante su disgregación; se establece así, con carácter automático, un sistema de frenos y contrapesos, checks and balances, que actúan como un mecanismo autorregulador.

Por otra parte, a este primer aspecto liberal de la Ley Orgánica se incorpora, por obra del acontecer histórico, una inspiración democrática, explícita en el texto constitucional de 1869, que instaura el sufragio universal (excluido el voto femenino) y establece el jurado como cauce de la participación del pueblo en la administración de la justicia. En el aséptico tronco liberal se injerta así el factor ético que implica el gobierno de la mayoría con el respeto de la minoría, dentro de una tendencia que había surgido imperiosamente a la luz en 1848 y puso en la escena histórica al proletariado. Estas dos directrices de la Ley Orgánica del Poder Judicial, una liberal y otra democrática, son peculiares de aquella época y, por ello, su autenticidad histórica ha permitido una insólita perdurabilidad. De ahí su carácter ejemplar, como consecuencia de la adecuación a las exigencias de su tiempo. En el nuestro, el planteamiento esencial sigue siendo válido pero insuficiente, ya que hoy la solidaridad humana reclama un puesto preferente.

La separación de los poderes nunca desconoció la unidad esencial de la soberanía. Por ello no resulta incongruente con tal planteamiento político la declaración solemne de que "la justicia se administrará en nombre del Rey", colocada en el mismo pórtico de la Ley Orgánica del Poder Judicial (art: $1 .^{\circ}$ ); fórmula, por otra parte, tradicional en todas nuestras constituciones, cualquiera que haya sido su matiz ideológico ${ }^{17}$. Conviene advertir también que la configuración del orden

17 Cfr.: 1808 , art. 98; 1812, art. $257 ; 1837$, art. $68 ; 1845$, art. $71 ; 1856$, art. 72 ; 1869 , art. $91 ; 1876$, art. 74 . También en el proyecto de 1836, art. 43 , y en el anteproyecto de 1929, art. 93. La Justicia se administra en nombre del Estado, proclamaba la Constitución de 1931 (art. 94). En nombre del Jefe del Estado, puntualiza la Ley Orgánica de 1967 (art. 29). 
judicial como "poder" constituye en esta Ley una noble aspiración que, sin embargo, aparece menoscabada en la realidad de su instrumentación técnica. La fuerza institucional que significa la unificación de fueros, conseguida entonces, se debilita quizá deliberadamente mediante el principio organizativo de la colegialidad y el excesivo número de jueces que tal estructura implica. La evolución posterior ha agudizado estos factores negativos $y$, en cambio, no ha sabido conservar la energía positiva que suponía la concentración jurisdiccional.

Una de las preocupaciones permanentes de nuestro liberalismo decimonónico y especialmente de su sector progresista fue la unificación jurisdiccional, corolario del principio de igualdad y conectado también con la tendencia centralizadora. Desde una perspectiva institucional, se convierte en el fundamento sustantivo de la justicia como poder. El Estatuto de Bayona suprimía los tribunales con atribuciones especiales y todas las justicias de abadengo, órdenes y señoríos (art. 98). Con mayor precisión proclamaba la Constitución doceañista que "en los negocios comunes, civiles y criminales, no habrá más que un solo fuero para toda clase de personas", si bien se respeten las jurisdicciones eclesiástica y militar (arts. 248, 249 y 250). Esta declaración no vuelve a formularse explícitamente en ningún texto constitucional posterior y sólo es recogida de modo implícito al establecerse en 1837, 1845 y 1856 el carácter "exclusivo" de la potestad judicial ${ }^{18}$.

La Ley de Bases de 11 de abril de 1868, en las postrimerías del período isabelino, autorizaba al Gobierno para elaborar una Ley completa y definitiva de ordenación judicial y competencia de los tribunales del fuero común, asi como para introducir mientras tanto las reformas más urgentes. Entre éstas se incluye expresamente la supresión de los fueros de guerra, marina y extranjería en lo respectivo a los negocios civiles (salvo la prevención de los juicios de testamentaría y abintestato) y también la extinción de los juzgados especiales de

18 La unidad de fueros se proclama también en el artículo 75 de la Constitución de 1876, en el artículo 94 del anteproyecto de 1929 y en el artículo 95 de la Constitución de 1931, que es muy explícito a este respecto, ya que encuadra en la Administración de Justicia todas las Jurisdicciones existentes, limita la castrense a los delitos militares $y$ prohíbe el establecimiento de fuero alguno por razón de las personas o de los lugares, salvo en estado de guerra, aboliendo todos los tribunales de honor. La Ley Orgánica de 1967, dentro de esta ininterrumpida tendencia constitucional, reserva con carácter exclusivo a los órganos judiciales comunes la función jurisdiccional, con la salvedad de las jurisdicciones militar y eclesiástica (arts. 31 y 32 ). 
Hacienda y tribunales de Comercio, devolviéndose el conocimiento de todos estos asuntos al fuero común o jurisdicción real y ordinaria (art. $2 .^{\circ}, 1^{\mathrm{a}}$ y $\left.2 .^{\mathrm{a}}\right)$.

\section{Los hombres de toga}

En este período, que abarca desde 1851 hasta 1874, la ciencia jurídica ofrece un aspecto poco brillante. En 1852, el 15 de diciembre, sale a la calle en Burgos el primer número de El Consultor de los Ayuntamientos, obra de don Marcial Martínez Alcubilla, a quien luego sucedería en la dirección don Fermín Abella y Blave ${ }^{19}$ y al año siguiente nace la Revista General de Legislación y Jurisprudencia, fundada por don José Reus y don Ignacio Miquel, con la incorporación en 1857 de don Pedro Gómez de la Serna. Este mismo año se crea la Academia de Ciencias Morales y Políticas. En el sector público van desapareciendo las grandes figuras de la primera mitad del siglo sin dejar discípulos. Pone de manifiesto claramente tal mediocridad, la circunstancia de que el Derecho administrativo se encuentra representado en esta época por Marcelo Martínez Alcubilla, autor del conocido Diccionario de la Administración española, cuya primera edición data de 1858. Cos Gayón publica también un Diccionario manual de Derecho administrativo español (1860), en colaboración con Emiliano Cánovas del Castillo. En materia financiera habian aparecido el Tratado de la Hacienda de España y el Examen económico-histórico-político de la Hacienda y Deuda del Estado (1838 y 1840, respectivamente), obras de Peña y Aguayo. Posteriormente surge la figura de Eustaquio Toledano, profesor universitario, que compone el Curso de Instituciones de Hacienda Pública en España (1859-1860), tratado omnicomprensivo, carente de un esquema sistemático y, quizá por ello, farragoso, pero cuyo valor no debe ser menospreciado, ya que significa un ingente esfuerzo personal y una aportación científica sin par en su tiempo. Finalmente, conviene mencionar a Laureano Figuerola y Ballester, catedrático de Derecho público y ministro de Hacienda en el Gobierno provisional, que implantó la "peseta" como unidad monetaria. Su fecunda actuación al frente de tan delicado departamento durante diez

19 Otras revistas jurídicas, algunas efímeras, aparecen en esta época: $L a$ Themis (1857-58), El Eco de la Ley (1859-61), La Voz de los Ayuntamientos (186062). El Monitor de la Salud (1858-64) y el Boletín de Administración Local, Depósitos y Juzgados Municipales (1861-1933). 
meses puso de relieve un conocimiento poco habitual de los principios financieros y un menos frecuente sentido de la realidad; es lástima que en su doble personalidad político-científica prevaleciera aquélla y dejara inédita su valiosa experiencia ${ }^{20}$.

\section{LO CONTENCIOSO-ADMINISTRATIVO}

\section{Nacimiento y configuración}

Lo contencioso-administrativo es otro de los temas polémicos de nuestro siglo XIX. Progresistas y moderados incluyen en los respectivos programas políticos sus diferentes concepciones de la justicia administrativa ${ }^{21}$. La polémica desde posiciones extremas e irreductibles sólo encontrará solución en 1888, mediante una auténtica concordia, producto en gran parte del cansancio y también del ambiente doctrinario de la época.

El Estatuto de Bayona estableció ya un Consejo de Estado, presidido por el Rey, dentro de cuyas atribuciones meramente consultivas se encontraba el conocimiento "de la parte contenciosa de la Administración", así como de los conflictos jurisdiccionales y de la citación a juicio de los agentes o empleados de la Administración Pública (arts.

20 Castán Vázouez, José María, Pequeña historia de la "Revista General de Legislación y Jurisprudencia” (1853-1953), Madrid, 1953; GARRIdo FALLA, Fernando, Tratado de Derecho Administrativo, Parte general, vol. I, 2. ${ }^{2}$ ed., IEP, Madrid, 1961, pág. 152; EstAPÉ, Fabián, Prólogo a Elementos de Ciencia de Hacienda, de José CANGA ARGÜELLES, reedición, Madrid, 1961; Nieto GARCía, Alejandro, Influencias extranjeras en la evolución de la ciencia española del Derecho administrativo, Anales de la Universidad de La Laguna, Facultad de Derecho, III, 1965-1966, fasc. 1. ${ }^{\circ}$, págs. 43-68; VILLAR PALASI, José Luis, "La dinámica del principio de legalidad presupuestaria", Revista de Administración Pública, n. ${ }^{\circ} 49$, enero-abril de 1966, pág. 14.

21 Como testimonios significativos, entre tantos que podrían aportarse, valgan dos: José DE Posada Herrera, en la página IX del Prólogo a Lo contenciosoadministrativo de GALLOSTRA, escrito en forma epistolar desde Llanes el 30 de septiembre de 1880, alude al hecho de que uel partido democrático escriba en su bandera la supresión de los Consejos de Estado y provinciales» o "la derogación de la Jurisdicción contenciosa que al presente ejercen", mientras que su creación, mantenimiento y restauración como Jurisdicción retenida fueron obra del partido conservador, según enfáticamente pone de relieve el Conde de TEJADA DE VALDOSERA en su artículo sobre «El restablecimiento de la jurisdicción contencioso-administrativa" $y$ el Decreto de 20 de enero de 1875, recogido en el libro Lo contencioso-administrativo, Madrid, 1892, págs. 63-64. 
52, 58 y 59). La Constitución de 1812 creaba también un Consejo de Estado, que habría de ser oído "en los asuntos graves gubernativos» (art. 236), expresión ambigua que, sin embargo, el párrafo $X X X$ del discurso preliminar configuraba con alguna mayor precisión: "En él se habrá de refundir el conocimiento de los negocios gubernativos que andaban antes repartidos entre los Tribunales supremos de la Corte con grande menoscabo del augusto cargo de administrar justicia, de cuyo santo ministerio no deben ser en ningún caso distraídos los magistrados: y porque también conviene determinar con toda escrupulosidad y conservar enteramente separadas las facultades propias y características de la autoridad judicial". Este criterio hubiera permitido probablemente, dentro de la lógica del sistema, el nacimiento de una jurisdicción contencioso-administrativa. Sin embargo, ninguno de ambos textos constitucionales tuvo eficacia real, por lo que la situación en este aspecto permaneció inalterada.

En cambio, el Decreto de 13 de septiembre de 1813, aprobado por las Cortes generales y extraordinarias como consecuencia de la supresión del Consejo de Hacienda, encomendaba a la Administración de Justicia el enjuiciamiento de utodos los negocios contenciosos de la Hacienda Pública", incluso "las causas y pleitos sobre contratos generales y particulares", así como "los asuntos contenciosos que ocurran sobre liquidación de cuentas». De aquéllos conocerían los Jueces letrados y las Audiencias en segunda y tercera instancia, según el artículo 262 de la Constitución; de la "vista y revista" en materia contable conoce la Audiencia de la Corte, asesorada por "un individuo de la Contaduría mayor o de la Junta Nacional del Crédito Públicon. Este sistema quedó sin efecto en el trienio constitucional, por el Decreto parlamentario de 25 de junio de 1821 (obra de Canga-Argüelles), que prohíbe a los Tribunales ordinarios el juicio de tales reclamaciones (art. 199), que se reserva a la propia Administración pública, mediante Juntas de agravios provinciales 22 .

Tampoco significaron novedad alguna el Consejo de Estado que creó Fernando VII en 1825, ni el Consejo Real establecido por la Reina Gobernadora en 1834 y suprimido tres años después. En consecuencia, durante este período no existe la jurisdicción contencioso-administrativa, aun cuando naturalmente se produjeran algunos conflictos

22 MendizÁBal Allende, Rafael: «La crisis del "antiguo régimen" y la jurisdicción contable", Revista de Legislación y Jurisprudencia, enero 1967, tomo LIV de la segunda época, n. 1 , págs. 12-74. Existe edición separada, Reus, S. A., Madrid, 1967. Cfr. págs. 11-12 (especialmente nota 10), 14 y 38-40. 
y reclamaciones respecto de los actos de la Administración, que resolvían los ministros de la Corona ${ }^{23}$. Por ello, en 1838 se constituye una comisión de notables para organizar esta jurisdicción, sin que el proyecto elaborado llegara a convertirse en Ley. Sin embargo, el dato revela que en esta época se adquiere conocimiento de la necesidad de "una jurisdicción especial de naturaleza difícil y compleja, distinta en la esencia y en la forma de la jurisdicción ordinaria, que pueda conocer de los negocios contencioso-administrativos y decidir definitivamente sobre ellos", según explica la exposición del Decreto de 24 de diciembre de 1843, que establece otra comisión con tal finalidad, en la que figuran nombres ilustres del Derecho administrativo y en la que tuvo una actuación decisiva el Magistrado don Francisco Agustín Silvela 24 .

Obra de esta comisión son las Leyes de 2 de abril y 16 de septiembre de 1845, que establecen por primera vez en España la jurisdicción contencioso-administrativa con carácter retenido, según el modelo francés. Era la propia Administración, mediante el Consejo de Ministros presidido por el Rey, quien pronunciaba la sentencia en forma de Real Decreto, acorde o no con el dictamen del Consejo Real. Dentro de éste se creó una sección de lo contencioso, que tramitaba las demandas interpuestas contra los actos de la Administración Central y los recursos de apelación contra los fallos de los Consejos Provinciales, así como los de casación y revisión contra las sentencias del Tribunal de Cuentas. Los Consejos Provinciales enjuiciaban en primera instancia las reclamaciones contra las resoluciones de la Administración local y estaban compuestos por tres o cinco vocales, bajo la presidencia del jefe político. Dependía de la propia Administración no sólo la decisión final, sino incluso la admisibilidad de las demandas, acerca de las cuales se pronunciaba, según los casos, el Gobernador, el Ministro o el Consejo de Ministros. El sistema expuesto era fiel reflejo de su modelo francés, aceptado casi unánimemente sin reservas por

23 Bravo, Julio: Comentarios a la Ley de 13 de septiembre de 1888, Madrid, 1888, pág. 17; Gallostra Y FRAU, José: Lo contencioso-administrativo, Madrid,. 1881, pág. 79.

24 La comisión estaba formada por los señores don Francisco Javier Istúriz, Duque de Frías, don Francisco Agustín Silvela, el Obispo de Zamora, don Manuel Joaquín Tarancón, el Teniente General don Antonio Remón Zarco del Valle, don Francisco Javier de Burgos, don José Posada Herrera, don Alejandro Mon, el Jefe de Escuadra don Francisco Baltasano, don Alejandro Oliván y el General don Joaquin Ezpeleta. Esta comisión elaboró los anteproyectos con base en el proyecto de Ley que había presentado Silvela en las Cortes de 1838. 
los cultivadores del Derecho administrativo de la época ${ }^{25}$. Era también el criterio del partido moderado, entonces en el poder.

En el bienio progresista se modifica el anterior sistema, aunque las innovaciones sean más aparentes que sustanciales. Son suprimidos por Decreto de 7 de agosto de 1854 el Consejo Real y los provinciales. Los asuntos contencioso-administrativos se encomiendan más tarde a las Diputaciones Provinciales y a un Tribunal Contencioso-administrativo, que sólo tenía de tal el nombre, pues no obstante su carácter de supremo, el Presidente y los doce ministros que lo formaban no estaban amparados por la inamovilidad y sus acuerdos eran meramente consultivos (Decreto de 10 de enero de 1855). La jurisdicción continuaba siendo retenida y, en consecuencia, difícilmente puede calificarse esta organización .como judicialista ${ }^{26}$. El Real Decreto de 16 de octubre de 1856 restablece la situación existente dos años antes. Así permanecerá hasta 1868, con ligeras variaciones: en 1860 el Consejo Real se convierte en Consejo de Estado y en 1863 se reorganizan los Consejos provinciales ${ }^{27}$.

En este sistema, que duró 56 años, lo contencioso-administrativo constituye una faceta de la potestad jurisdiccional de la Adminis-

25 Entre ellos, Silvela, Oliván, Posada Herrera, Gil de Zárate y posteriormente Abella; también Pacheco, con ciertas matizaciones respecto de los contratos administrativos. Cfr. Nieto, op. cit., págs. 35-37.

26 Alfaro y Lafuente, Santos, Tratado completo de lo contencioso-administrativo, Madrid, 1875, pág. 31, afirma que este Tribunal no ejercía jurisdicción propia. Gallostra, pág.. 81, y Bravo, pág. 31, coinciden en estimar que con tal sistema continuaba la jurisdicción retenida. SAnTAMARía de PAREdes, Vicente, Curso de Derecho administrativo, 3. ${ }^{a}$ ed., Madrid, 1891, pág. 841, se pronuncia en el mismo sentido. "No afectó a la esencia, sino a la forma", dice de esta reorganización CABALLERO, I., pág. 27.

27 Además de las obras de Alfaro, Bravo, Caballero, Colmeiro, Gallostra y Tejada de Valdosera, ya citadas o que se mencionarán más adelante, en todas las cuales puede seguirse el desarrollo histórico de lo contencioso-administrativo, deben consultarse también, ya desde una perspectiva actual, las siguientes: CoRDERo ToRres, José María, El Consejo de Estado, IEP, Madrid, 1944, págs. 85-102; GARCIA DE ENTERRIA, Eduardo, "La doctrina de los actos propios y el sistema de la lesividad", Revista de Administración Pública, n.²0, págs. 69-77; GonzÁlez Pérez, Jesús, op. cit., "Evolución y estado actual del recurso contencioso-administrativo", Revista del Instituto de Derecho Comparado, $n .^{\circ} 4$, enero-junio 1965, págs. 62 y ss.; MARTín-Retortillo, Sebastián: "La desviación de poder en el Derecho español", Revista de Administración Pública, $\mathrm{n} .^{\circ} 22$, págs. 129-175; Nieto GARCíA, Alejandro: "Los orígenes de lo contencioso-administrativo en España", Revista de Administración Pública, n. ${ }^{\circ}$ 50, mayo-agosto 1966, págs. 43-46; JoRDANA DE PozAS, Luis: "Le Conseil d'État espagnol et les influences françaises au cours de son évolution", Livre jubilaire... du Conseil d'État, París, 1952. 
tración pública. Su especialidad se constituye en función del objeto $y$, por lo tanto, se intenta delimitar mediante el acto administrativo, como el de comercio sirve de eje al Derecho mercantil. Se habla así de la "materia contencioso-administrativa», sin que falte algún intento tímido de convertirla en fuero común de la Administración ${ }^{28}$.

La concepción doctrinal, como la íntegra estructura de la Administración, es de origen francés y quizá late en la configuración objetiva de lo contencioso-administrativo un prejuicio residual respecto de los fueros privilegiados de carácter personal proscritos por el principio de igualdad ante la Ley. Sin embargo, el trasplante de la superestructura obtuvo resultados muy diferentes a los del modelo, ya que la realidad subyacente, más fuerte que cualquier esquema teórico, provocó una grave distorsión.

\section{La revolución de 1868}

Pues bien, una vez triunfante la revolución, se radicaliza este criterio del régimen precedente y se pone inmediatamente en marcha la unificación jurisdiccional, que es instrumentada mediante una serie de Decretos del Gobierno provisional. Primero son suprimidos el Consejo Real y los Consejos provinciales (13 de octubre), luego el Juzgado Especial de Imprenta (23 de octubre), inmediatamente después el Tribunal Especial de las Órdenes Militares ( 2 de noviembre) y, por fin, los Juzgados de Hacienda y los Tribunales de Comercio, conservándose las jurisdicciones eclesiástica y castrense, aun cuando reducidas a sus estrictos límites naturales (6 de diciembre). Así, la unificación tuvo efecto mucho antes de que fuera solemnemente proclamada en el artículo 91 de la Constitución de 1869. La Ley Orgánica del Poder Judicial parte de este planteamiento y consolida tal realidad, aunque las vicisitudes posteriores hicieran naufragar tan noble propósito.

28 GARCIA DE ENTERRÍA, Eduardo: "La configuración del recurso de lesividad", Revista de Administración Pública, n. ${ }^{\circ} 15$, pág. 111, final nota 1 . Sobre el significado originario de la jurisdicción contencioso-administrativa es fundamental la polémica de alto bordo intelectual mantenida por dos distinguidos juristas: PARADA, J. R.: "Privilegio de decisión ejecutoria y proceso administrativo", Revista de Administración Pública, n..$^{\circ} 55$, págs. 65 y 55. NIETO, Alejandro: "Sobre la tesis de Parada en relación con los orígenes de lo contencioso-administrativo", Revista de Administración Pública, n. ${ }^{\circ}$ 57, págs. 9-33; PARADA, J. R.: «Réplica a Nieto sobre el privilegio de decisión ejecutoria y el sistema contencioso-administrativo", Revista de Administración Pública, n. ${ }^{\circ}$ 59, págs. 41-70. 
La consagración absoluta del principio de unidad de fueros implicaba por su propia lógica interna el triunfo de la tendencia judicialista en orden a la configuración de lo contencioso-administrativo. En efecto, como ya quedó indicado, pocos dias después de la constitución del Gobierno provisional, un Decreto de 13 de octubre de 1868 «suprime la jurisdicción contencioso-administrativa... que ejercían el Consejo de Estado y los Consejos provinciales" (art. $1 .^{\circ}$ ) y, en consecuencia, declara extinguidos éstos y la sección de lo contencioso de aquél (art. 20), para encomendar el enjuiciamiento de tales asuntos al Tribunal Supremo y a las Audiencias. La competencia del Tribunal Supremo se extiende entonces al conocimiento de "las demandas que según la legislación hasta ahora vigente debían entablarse en primera y última instancia ante el Consejo de Estado" (art. 5. ${ }^{\circ}$ ) y a "los recursos de alzada y nulidad que en lo sucesivo se incoasen" (art. 4. $\%$, así como a «los negocios pendientes ante el Consejo de Estado... sustanciándose según el estado en que se encuentren". A las Audiencias se les entrega el enjuiciamiento de los encomendados anteriormente a los Consejos provinciales (art. $3 .^{\circ}$ ).

Conviene observar, ante todo, que este primer Decreto emana del Ministerio de la Gobernación, ya que los Consejos suprimidos le estaban adscritos ${ }^{29}$. El trasplante de la jurisdicción contencioso-administrativa desde la Administración pública al Poder Judicial implica una primera consecuencia formal: la competencia respecto de aquéIla se altera y corresponde desde entonces al Ministerio de Gracia y Justicia, del que procederán las demás normas que instrumenten esta operación ${ }^{30}$. Tal planteamiento judicialista se mantiene en sus líneas esenciales durante esta etapa política, si bien adoptará diversas manifestaciones orgánicas, que revelan plásticamente las dificultades que presentaba la experiencia. La reforma de lo contencioso-administrativo ofrece en este aspecto estructural tres fases muy definidas, que se exponen a continuación.

29 Colmelro, Manuel: Derecho administrativo español, 2. ${ }^{a}$ ed., I, Madrid, 1858, pág. 111. «Al (Ministerio) de Gobernación del Reino pertenecen: $1 .^{\circ}$ Las relaciones con el Consejo Real, Consejos provinciales...n.

30 Los Decretos a que se alude no aparecen firmados por el Jefe o Presidente del Poder ejecutivo, sino tan sólo por el ministro correspondiente con la fórmula uen uso de las facultades que me competen, como individuo del Gobierno provisional... de acuerdo con el Consejo de Ministros». El de la Gobernación era entonces don Práxedes Mateo Sagasta y de él procede el Decreto de 13 de octubre, mientras que los dictados el 16 de ese mismo mes y el 26 de noviembre emanan de don Antonio Romero Ortiz, ministro de Gracia y Justicia. 
La primera fase está constituida por el Decreto de 16 de octubre, que, para incorporar la jurisdicción suprimida a la Administración de justicia, "crea en el Tribunal Supremo de Justicia y en todas las Audiencias de la Península e islas adyacentes, una Sala que decidirá sobre las cuestiones contencioso-administrativas" (art. 1. ${ }^{\circ}$ ). Esta Sala "la formarán en el Tribunal Supremo, el Presidente del mismo y los dos de Sala más antiguos, y en las Audiencias el regente con los dos Presidentes también más antiguos» (art. $2^{\circ}{ }^{\circ}$. Con tal composición, al más alto nivel orgánico, se reconoce implícitamente la trascendencia de lo contencioso-administrativo. Conviene advertir que en principio se excluye del sistema a las Audiencias de Ultramar (La Habana, PuertoPríncipe, Puerto Rico y Manila) ${ }^{31}$. Aunque se facultaba al Presidente del Tribunal Supremo y a los regentes de las Audiencias para adoptar las disposiciones necesarias que exigiera la ejecución de este Decreto (art. 4. ${ }^{\circ}$ ), la realidad es que su texto resultaba excesivamente lacónico y en él "no se tuvieron en cuenta muchos detalles indispensables para la efectividad de la reforma, por lo que el Tribunal Supremo se abstuvo por algún tiempo de conocer de los nuevos asuntos que se sometían a su jurisdicción" ${ }^{32}$.

31 La Ley creando los Consejos de provincias no había sido extensiva a nuestras posesiones de Ultramar; así es que en éstas las Audiencias decidían en primera instancia los pleitos contencioso-administrativos, constituidos en Acuerdos. Para poner fin a esta confusión de atribuciones entre la Administración y la Justicia, se dictaron tres Reales Decretos con fecha 4 de julio de 1861: por el primero se privaba a las Audiencias de sus facultades administrativas, mandando que no pudiesen constituirse en Acuerdos para consultar ni fallar en los asuntos de la Administración, y limitando sus funciones a la Administración de Justicia; por el segundo se creaba para cada una de las provincias ultramarinas un Consejo de Administración, dividido en tres secciones, de las que una, llamada de lo contencioso, estaba encargada de conocer en los litigios administrativos, $y$, por el tercero, se determinaba el reglamento para el modo de proceder en estos asuntos. Posteriormente, en Ultramar se hicieron sentir los mismos cambios que en la Península. Dos Decretos, uno de 7 de febrero y otro de 2 de junio de 1869, habian confiado a las Audiencias Territoriales de aquellas provincias la jurisdicción contencioso-administrativa que antes ejercian las secciones de lo Contencioso de los Consejos de Administración, quedando éstos sưpimidos. Como era natural, al verificarse en la Península la restauración de los Tribunales administrativos, no podia dejar de hacerse otro tanto respecto a Ultramar, y así, se publicó un Decreto en 19 de marzo de 1875, dejando sin efecto los dos que anteriormente hemos citado, volviendo a declarar en vigor las disposiciones que existian en la materia antes de la revolución del 68. Cfr. Gallostra, op. cit., págs. 82,87 y 88 .

32 Alfaro y Lafuente, Santos: Tratado completo de lo contencioso-administrativo, Madrid, 1875, pág. 36. Tamblén GallostRA, op. cit., pág. 84. 
La segunda fase de este proceso evolutivo es el Decreto de 26 de noviembre, consecuencia de la imprecisión de los anteriores. EI Gobierno provisional encomendó al Presidente del Tribunal Supremo la preparación de las normas complementarias que estimara precisas, tarea que don Joaquín Aguirre de la Peña, canonista, realizó con gran acierto, asesorado por don Pedro Gómez de la Serna (que le sucedería en el cargo pocos meses después) y don Manuel Alonso Martínez, burgalés de pro. Este Decreto se refiere fundamentalmente al Tribunal Supremo, para operar en él la refundición de las jurisdicciones contencioso-administrativas y de las órdenes militares, aun cuando afecte también a las Audiencias. En realidad, constituye el primer paso de una nueva ordenación del poder judicial y a causa de su contenido procedimental fue calificado de "reglamento" por los juristas contemporáneos ${ }^{33}$.

El Tribunal Supremo de Justicia se reorganiza ahora en tres Salas (art. $1 .{ }^{\circ}$ ), de las cuales corresponde a la itercera el conocimiento de los negocios contenciosos de la Administración procedentes de la Península, islas adyacentes y provincias ultramarinas, ya sea en instancia única, ya en apelación o en recurso de nulidad" (párrafo último del art. $6 .^{\circ}$ y art. 19). Cada Sala se componia de un Presidente y ocho Ministros (art. $2 .^{\circ}$ ). Con ellos, dice el preámbulo, "bien puede formarse una Sala que entienda en los negocios contenciosos de la Administración. El número de ministros, la circunstancia de ser todos letrados, la práctica y hábito de juzgar de los que están en el término de su carrera, la experieńcia que han atesorado, sustituye a la garantía de acierto que respectivamente ofrecían la Sección y la Sala de lo Contencioso del Consejo de Estadon.

Sin embargo, ni todos sus componentes ni sólo ellos formaban siempre la Sala. Ésta se constituía de diversa forma, según la índole de los asuntos. En efecto, eran suficientes tres ministros para las providencias de sustanciación que no tuvieran señalado otro número especial y siete para las sentencias definitivas, las providencias sobre la admisibilidad de las demandas, las resolutorias de la reposición de otras $y$ las aclaratorias de todas aquellas que requieran el mismo número. En cambio, se exigia la presencia de once ministros para los recursos en que hubiera informado el Consejo de Estado en pleno, así como para los de revisión y sus aclaraciones; en tales casos la Sala se completaba con el Presidente del Tribunal y otro de Sala (art. 5. ${ }^{\circ}$. EI 
preámbulo explica que esta composición extraordinaria "será salvaguardia bastante para la garantía de todos los derechos legítimos, sin que se rebaje por eso la autoridad de los fallos que el Consejo de Estado proponía en pleno".

Además del personal judicial ya enumerado, se adscribían a la Sala Tercera dos abogados fiscales para ocuparse exclusivamente de los negocios contencioso-administrativos; tres secretarios relatores, todos letrados, para dar cuenta de los asuntos y asistir a las vistas, con fe pública; dos ujieres, cuyas funciones habian de ser las que señalaba a sus colegas las normas reglamentarias hasta entonces vigentes, y los porteros que asignase a su servicio el Presidente del Tribunal Supremo (arts. $12,13,15$ y 16). El preámbulo justifica esta planta de personal y aduce que el número de los subalternos necesarios ues el menor posible», hasta el extremo de que "tal vez habrá necesidad de algún auxiliar más: la experiencia demostrará en su caso la conveniencia del aumento". En la Sala Tercera del Tribunal Supremo no percibirá honorarios ninguno de sus subalternos (art. 17), expresión ésta comprensiva de todos los funcionarios de la Secretaría, retribuidos exclusivamente mediante sueldo ${ }^{34}$.

En las Audiencias corresponde ahora a su Sala Primera el conocimiento de los negocios contenciosos de la Administración pendientes o que en lo sucesivo se incoaren, de que conocían antes los Consejos provinciales (art. 18). En el ámbito geográfico se hace regional la anterior competencia provincial, transformación que anticipa la operada en 1956. Las demandas contencioso-administrativas se interpondrán directamente en la Sala Primera de la Audiencia del territorio a la que correspondan las provincias en que debian comenzarse según el sistema anterior (arts. 18 y 23). Los relatores, los escribanos de Cámara y demás subalternos de las Salas correspondientes, según sus respectivos cargos, desempeñarán las funciones que con arreglo a las normas procesales peculiares en la materia, correspondía a los Secretarios y ujieres, sujetándose respecto al percibo de derechos a los aranceles establecidos para los negocios comunes (art. 22).

El mismo preámbulo tantas veces citado explica que uen las Audiencias serán escasos los negocios contenciosos de la Administración; así lo hace presumir lo que hasta ahora ha acontecido en los

34 Las dotaciones eran: 2.800 escudos anuales los abogados fiscales y los secretarios relatores (más 600 estos últimos para gastos de escritorio) y 1.400 escudos cada ujier. 
Consejos provinciales; no es necesario, por lo tanto, aumentar subalternos, bastando con los que actualmente tienen las Salas, los cuales podrán muy bien desempeñar funciones análogas a las de los Secretarios y ujieres de los Consejos provinciales. No sería tampoco conveniente nombrar nuevos empleados para tan escasos negocios, ni que hubiera en una Sala distinta clase de cargos para llenar funciones de una misma naturaleza, por más que los procedimientos sean diferentes. Como la remuneración de estos subalternos consiste principalmente en los derechos que perciben, se ha establecido que se arregle a los aranceles que rigen para los negocios comunes".

La tercera fase en la evolución estructural de la jurisdicción contencioso-administrativa aparece constituida por la promulgación de la Ley Orgánica del Poder Judicial. Aun cuando su delimitación del contenido de la potestad de aplicar las leyes (art. $2 .^{\circ}$ ) se refiere tan sólo a los juicios civiles y criminales ${ }^{35}$, establece, sin embargo, una Sala en el Tribunal Supremo - la Cuarta - para conocer «en única instancia y en revisión de todos los recursos que con arreglo a la Ley entablen contenciosamente los que se sintieran agraviados en sus derechos por resoluciones de la Administración general del Estado que sean definitivas" (art. 282), asi como también en única instancia de las recusaciones que se interpusieren contra los magistrados que la integran, a excepción del Presidente (art. 283).

Según esta misma Ley, las Audiencias se organizaban en Salas de lo Civil y Salas de lo Criminal (más la de Gobierno y el Pleno), sin que entre las atribuciones de cualquiera de ellas se incluyera en ningún instante el enjuiciamiento de los negocios contencioso-administrativos. Tal silencio está relacionado con la omisión de toda referencia al recurso de apelación y a la Administración local en la delimitación de la competencia del Tribunal Supremo. No obstante, las Audiencias siguieron resolviendo tales asuntos sin estar autorizadas por la nueva Ley, como otra de 1 de marzo de 1873 confirma $^{36}$. Los comentarios de los autores contemporáneos insisten con unanimidad en que tal silencio resulta completamente inexplicable ${ }^{37}$. Bravo achaca la omisión «al

35 Lo contencioso-administrativo, como una de las facetas de la potestad judicial, aparece ya en el proyecto constitucional de 1929 (art. 93, 2) y adquiere consistencia jurídica por primera vez en la Ley Orgánica del Estado (art. 31).

36 Así lo afirma también AlFaro, pág. 42.

37 "Resulta inexplicable», afirma ALFARO, pág. 42 "iCosa extraña y completamente inexplicable!», dice Gallostra, pág. 84. «Extraño caso», comenta Bravo, pág. 35. CaBallero, l, pág. 36 , anota el hecho sin más. 
olvido a que esta materia había sido condenadan 38 , mientras que Alfaro rechaza una serie de hipótesis: "No podemos atribuir tal omisión a error de imprenta, pues no es concebible que se hubiesen cometido dos defectos en dos artículos diferentes y que tenían gran relación entre sí. Tampoco podemos atribuirla a que la mente del legislador acariciara la idea de suprimir esta jurisdicción, pues lo hubiese dicho terminantemente, $y$ mucho menos podemos creer que se le quisiera dar otra forma diferente, pues en este caso se hubieran dictado disposiciones provisionales, como se hizo en 1854 para evitar los perjuicios que pudieran seguirse de la paralización de la justicia administrativa, - la anomalía de que entendiesen los Tribunales de ciertos negocios acerca de los cuales no se había concedido jurisdicción por la Ley Orgánica de aquéllos» ${ }^{39}$.

Es muy posible que el defecto señalado fuera producto de diversos factores: la excesiva velocidad en la redacción definitiva de la Ley Orgánica, sobre un anteproyecto elaborado con un criterio radicalmente distinto respecto de la jurisdicción contencioso-administrativa; la inestabilidad de la situación política que polarizaba la atención de todos y favorecía el olvido de problemas secundarios, y también quizá la indecisión de los redactores de la Ley en orden a la naturaleza compleja de lo contencioso-administrativo, su carácter polémico, según se reconocía en el preámbulo del Decreto de 26 de noviembre. La coyuntura no era propicia para el uexamen y detenido estudio" de esta cuestión importantísima, que prometía el Gobierno provisional.

\section{La Ley Orgánica del Poder Judicial}

\subsection{Finalidad de la reforma}

La finalidad, el fundamento y el significado de la reforma aparecen recogidos ex post facto en el extenso preámbulo del Decreto de 26 de noviembre de 1868, que dedica algo más de las dos terceras partes de su contenido total a lo contencioso-administrativo. Allí se encuentran, con cierta encantadora promiscuidad, razones dogmáticas y

39 Alfaro, op. cit., pág. 42. 
motivos políticos, principios constitucionales y argumentos polémicos. Unos y otros ofrecen un valor desigual, pero siempre sugestivo y aleccionador.

Observa Nieto que hoy suelen considerarse estas reformas como una medida de exclusiva intención política, pero no es asi ${ }^{40}$. En realidad, perseguía una finalidad múltiple, algunas de cuyas facetas quedan explícitas mientras otras permanecen en la sombra, si bien no cabe desconocer que el propósito predominante fuera evidentemente de carácter político.

En tal aspecto, la nueva configuración de la jurisdicción contencioso-administrativa constituye un reflejo de la separación de los poderes, que se lleva hasta sus últimas consecuencias, en una interpretación más próxima al modelo anglosajón que al francés, como ya fue observado en su época. La unidad de fueros exige en esta misma tendencia que se reintegren al poder judicial las jurisdicciones desgajadas y extravagantes. Los tribunales, por ello, enjuician lo contencioso-administrativo en virtud de su potestad exclusiva de administrar justicia, sin que esto implique que "sean invadidas las funciones de la Administración activa", según objeción habitual de los partidarios del sistema administrativo. De tal forma se pretende otorgar "a los derechos legítimos toda la protección, toda la garantía que necesiten si no han de ser menoscabados". La "salvaguardia" de estas garantías tiene una faceta orgánica, como es por sí misma la propia judicialización, y otra procesal, que consiste fundamentalmente en la pérdida por la Administración de sus prerrogativas. Tales son las "altas aspiraciones» de la reforma, confesadas en el preámbulo.

También existió una motivación financiera, si bien la nueva organización no tuviera "por único ni por principal objeto hacer una economía en el presupuesto del Estado". No obstante su accesoriedad, se encuentran en el preámbulo varias referencias al propósito de reducir el gasto público. En tal sentido se afirma que la nueva planta del Tribunal Supremo supone una cantidad muy pequeña "si se compara con la que señalaba el presupuesto de la Sección de lo Contencioso y sus dependencias. Cualquier otra organización sería más gravosa al Erario". También en las Audiencias, la utilización del personal judicial y subalterno propio, sin aumento alguno, permitía prescindir de los Secretarios y ujieres de los Consejos provinciales, cuya supresión no 
dejaba «tras sí ningún gravamen ni en los presupuestos de las provincias ni en los generales del Estadon.

\subsection{Subsistencia de lo contencioso-administrativo. Su naturaleza problemática}

El hecho de suprimir la jurisdicción contencioso-administrativa no significaba el desconocimiento de "la diferencia que existe entre lo contencioso-administrativo y lo contencioso-judicial», según expresión alambicada del preámbulo del Decreto de 26 de noviembre. La postura del Gobierno provisional en tal aspecto es dubitativa, y por ello, promete un "detenido estudio de esta cuestión importantísima" antes de decidir, ya que la solución se enlaza con la conveniencia de mantener sus peculiaridades procesales. «Estos puntos bien merecen ser estudiados antes de adoptar una disposición definitiva que, respetando todos los derechos, concilia con los altos fines de la Administración los principios eternos de la justicia»; por ello, la reforma tiene en principio un alcance provisional y transitorio.

El preámbulo, por su carácter polémico, entra en el análisis de la naturaleza intrínseca de lo contencioso-administrativo y clasifica los asuntos de que hasta entonces conocía esta jurisdicción especial en dos grupos, perfectamente diferenciados según otros tantos criterios.

a) El primero está constituido por aquellas cuestiones en las que «el Estado, los pueblos y las corporaciones son personas jurídicas a cuyas contiendas debe aplicarse la ley civil, puesto que se refieren a la propiedad o a la contratación, materias definidas por la ley común. No es obstáculo para ello que los juzgadores deban tener presentes en su aplicación disposiciones administrativas. Lo mismo sucede en toda clase de obligaciones litigiosas, ya que no sólo se toman en cuenta las prescripciones formuladas en las leyes, sino también las condiciones de los contratos, que son leyes especiales de cada uno por voluntad de los contrayentes". Estas "cuestiones, que por su indole corresponden al poder judicial, han salido de su legítima competencia, como no pueden menos de confesar los partidarios más decididos de coexistencia de ambas jurisdicciones, diciendo que ésta es una transmutación y una excepción de los principios". En consecuencia, resulta indudable que a la jurisdicción ordinaria corresponden por su naturaleza, entre otros asuntos, los siguientes: 
$11^{\circ}$ Venta de bienes nacionales (desamortización).

2. Deslinde y amojonamiento de montes pertenecientes al Estado, a pueblos o a establecimientos públicos.

3. Expropiación forzosa que es causa de utilidad pública, cuando se trata de la observancia o quebrantamiento de las formas establecidas por las leyes.

4. Contratos relativos a servicios y obras públicas: cumplimiento, interpretación y daños y perjuicios ocasionados en su ejecución.

b) El segundo grupo aparece constituido por «los negocios que no caen bajo las prescripciones de los Códigos civiles, sino que son leyes puramente administrativas». En este caso, si se trata de «derechos legitimos... escritos en una Ley o en una disposición de carácter general", que puedan resultar lastimados o perjudicados, "es cuestión muy debatida si... deben éstos ser ventilados en forma contenciosa, o de otra manera, que reuniendo todas las prendas de acierto, no saque de su natural terreno lo que por su indole corresponde a la Administración activa; o si, por el contrario, debe atribuirse a lo contencioso-judicial... de tal modo que constando los hechos, sólo reste aplicar el texto invocado en apoyo del derecho controvertido".

\subsection{Judicialización}

La judicialización es ahora absoluta y coherente, no simplemente verbal como en el fugaz experimento progresista de 1854. "La jurisdicción retenida ha desaparecido por completo" - proclama el preámbulo-, y con deliberada precisión terminológica se abstiene de llamar "delegada" a la que ahora se integra en el Poder Judicial. "Los tribunales - añade - entran a funcionar en virtud de su misión de administrar justicia; ésta debe ser siempre independiente, libre, exclusiva: otra cosa sería incompatible con nuestras instituciones". "La jurisdicción del Tribunal Supremo es siempre propia, directa...". La operación de injerto consiste en restituir a la Administración de Justicia "lo que de ella se había desmembrado" y consumar la "devolución de cuantas cuestiones habían salido de su legítima competencia".

"Es un hecho en España - comentaba por entonces Alfaro- la existencia de tribunales que entienden con jurisdicción propia en los 
negocios contencioso-administrativos» ${ }^{41}$. Posteriormente, el profesor Santamaría de Paredes, cuya huella en esta materia fue indeleble, incurría, sin embargo, en la falta de rigor que implicaba identificar la jurisdicción "delegada" y la propia que ejercieron el Tribunal Supremo y las Audiencias desde 1868 a 1874, clasificando tal sistema con su peculiar criterio taxonómico, dentro del grupo judicial ecléctico, por corresponder a órganos especiales dentro de la Administración de Justicia42. En nuestros días se reconoce que esta reforma «instaura el sistema judicial en toda su pureza", según expresión de López Rodó ${ }^{43}$. Su consecuencia inmediata fue la configuración netamente procesal de lo contencioso-administrativo, que conserva, por otra parte, terminología tradicional. Así los tres Decretos de 1868 aluden a las "cuestiones", "demandas", "asuntos", "negocios" y sólo una vez son calificados tales conflictos como "recursos" (art. $5^{\circ}$ del de 26 de noviembre), aun cuando sea precisamente ésta la expresión que recoge luego la Ley Orgánica del Poder Judicial.

\subsection{Consecuencias procesales}

Lo contencioso-administrativo, como conjunto de conflictos sometidos a un régimen jurídico especial, permanece. Su diferente naturaleza intrínseca respecto de las cuestiones civiles, reconocida explícitamente, encuentra su reflejo formal en un cauce procesal propio y distinto 44 . Por ello se conserva la manera de proceder en los negocios contenciosos de la Administración de que conozcan tanto el

41 Alfaro, op. cit., pág. 41.

42 SANTAMARIA, op. cit., págs. 841 y 892 (discurso en el Congreso de los Diputados, pronunciado el 14 de diciembre de 1887, sobre la totalidad del proyecto de Ley de lo contencioso-administrativo).

43 López Rodó: Evolución..., págs. 63 y ss. También «Le recours contentieuxadministratif en Espagne", Revue Internationale des Sciences Administratives, 1953, pág. 168.

44 Así lo reconocen Alfaro Gallostra, pág. 83, y Bravo, págs. 33-34. TejaDA DE VALDOSERA, págs. 61-62, afirma explícitamente que en 1868 no se extinguió "de hecho la jurisdicción contencioso-administrativa"; "perdió aquélla alguna de las condiciones con que la venían ejerciendo el Consejo de Estado y los Consejos provinciales"' por la irrevocabilidad de las sentencias y la decisión acerca de la admisibilidad de las demandas. Sin embargo - añade - «conservó en gran parte la condición esencial de toda jurisdicción especial", "la particularidad del juez o jueces que la constituyen", sin que se confundieran "los asuntos contencioso-administrativos $y$ contencioso-ordinarios» ni se unificara el procedimiento. 
Tribunal Supremo como las Audiencias 45 , si bien se introduzcan algunas "alteraciones absolutamente imprescindibles", aun cuando muy importantes (art. $6 .^{\circ}$ del Decreto de 13 de octubre, y $7 .^{\circ}$ y 20 del de 26 de noviembre). «Esta medida -explica el preámbulo- ha tenido por principal objeto satisfacer a la apremiante necesidad de que no se paralizara la marcha de los pleitos ni se perjudicaran derechos; pero la solución definitiva de este punto se enlaza con la cuestión antes indicada sobre si debe existir o no lo contencioso-administrativo, con la extensión o las limitaciones que pueda tener en adelante. Sería prematuro e inconveniente por ahora hacer alteraciones transitorias que acarrearían, como es de suponer, los perjuicios consiguientes a los cambios en la forma de seguir los pleitos y en particular para los que ya se hallan incoados".

Las modificaciones que se introducen son una consecuencia ineludible del nuevo planteamiento de la jurisdicción contencioso-administrativa y de su configuración netamente judicial. Todas ellas responden a la finalidad explícita de salvaguardar los derechos legítimos o establecer una mayor garantía para los particulares, y se traducen en una pérdida de prerrogativas por parte de la Administración pública, que se sitúa en un plano procesal simétrico del ocupado por el ciudadano. En definitiva, se parte del principio, hoy evidente, de que "la Administración... por alta importancia que tenga en sus respectivas esferas, en el orden del juicio sólo le corresponde el carácter de litigante". Las alteraciones procesales, consecuencia de las orgánicas, pueden encuadrarse en el somero esquema sistemático siguiente:

"No cabe demostración práctica más concluyente - comenta en una nota al pie de la página 63- de la imposibilidad que presenta el suprimir en España la jurisdicción contencioso-administrativa. Se la puede desnaturalizar, encomendándola a los Tribunales ordinarios; pero no se la puede destruir. Tales raíces ha echado en nuestras costumbres».

45 Las normas reguladoras eran, según el mismo artículo $7 .^{\circ}$ del Decreto de 26 de noviembre, la Ley Orgánica del mismo Cuerpo, dada en 17 de enero de 1860; el Reglamento sobre el modo de proceder el Consejo Real en los negocios contenciosos de la Administración, de 30 de diciembre de 1846; el Real Decreto de 19 de octubre de 1860, y las demás leyes y disposiciones que han venido rigiendo hasta aquí en los negocios contencioso-administrativos, con las modificaciones que quedan ya establecidas y las que establecen los artículos siguientes. En el mismo sentido, el artículo 20 señala que las Audiencias, en los pleitos contencioso-administrativos, se atendrán en sus procedimientos, incluso los de prueba, al Reglamento de 1 de octubre de 1845, sobre el modo de proceder los Consejos Provinciales, y a las demás disposiciones que la competan, sin más excepciones que las que se establecen en esta Ley. 


\subsubsection{Representación y defensa de los litigantes}

El preámbulo expresa que «el Ministerio Fiscal es parte en todas las demandas en que tiene interés el Estado y en casi todas en que se interesa la Administración provincial y municipal», por lo que actúa con tal carácter, tanto ante el Tribunal Supremo como ante las Audiencias, según recogen los artículos 12 y 21 del texto.

En cuanto a los particulares, la Ley de 1 de marzo de 1873, proclamada ya la República, estableció que ulas partes contrarias a la Administración o coadyuvantes de ella podrán designar por sí mismas, o por medio de los Abogados que las representen y defiendan, un procurador bajo cuya responsabilidad y por cuyo conducto se entreguen a los letrados los autos de todos los casos en que, según el procedimiento vigente, se ponen de manifiesto en la Secretaría del Tribunal y a cuyo cargo estarán las cuestiones necesarias para la debida representación de los interesados".

\subsubsection{Incidente previo acerca de la admisibilidad de la demanda}

La admisión de las demandas contencioso-administrativas se encomienda al Tribunal Supremo y a las Audiencias, suprimiendo este privilegio que se arrogaba la Administración activa. Como aclara el preámbulo, "lo que en el supuesto de existir la jurisdicción suprimida podría ser lógico, cambiando el sistema, sería un contrasentido y degeneraría en el absurdo". Entre la Administración de justicia y los litigantes no debe haber intermediario alguno, y menos puede serlo la Administración... Separarse de esto equivaldría al restablecimiento de la jurisdicción retenida». Por otra parte, «no es de temer que la facultad que se atribuye al Tribunal Supremo (y a las Audiencias) de admitir las demandas contencioso-administrativas sin ulterior recurso, dé lugar a que sean invadidas las funciones de la Administración activa. El Ministerio Fiscal... saldrá sin duda al encuentro de toda extralimitación del Tribunal, acudiendo a la autoridad del orden administrativo a quien corresponda promover la competencia, que en último resultado habrá de dirimir el Gobierno, después de oír en pleno al Consejo de Estado. No se descuidarán tampoco los particulares en los pocos casos en que no sea parte el Ministerio Fiscal: el que no lo haga, cúlpese a sí mismo y sufra la pena de su negligencia, como sucede en toda clase de actuaciones judiciales».

En consecuencia, una vez presentada cualquier demanda, se oirá, por vía de instrucción, sobre su procedencia al Ministerio Fiscal, 
aunque no deba ser parte en el pleito ${ }^{46}$. Si éste no se opusiere, declarará la Sala su admisión cuando lo considere procedente. Si el Fiscal hiciere oposición o la Sala considerase que su admisión requiere mayor examen, o que es improcedente, se señalará dia para la vista con citación de las partes, debiendo decidirse este punto dentro del tercer día, fundando siempre la resolución, la cual producirá ejecutoria (art. 8. $^{\circ}$ ). Para comprender el alcance de esta norma, conviene acudir, una vez más, al preámbulo, que dice: "Otra innovación se hace en la manera de proceder en estos negocios. La Ley Orgánica del Consejo de Estado estableció que cuando la Sección estimase que la procedencia o improcedencia de una demanda necesitaba mayor examen, precediera vista en la Sala de lo Contencioso para preparar la consulta. Hubo un tiempo en que esta regla se aplicó no sólo a los casos expresos en la Ley, sino siempre que la Sección ópinaba que la vía contenciosa era improcedente. Después se alteró esta práctica, bastando que la Sección opinara resueltamente que no procedía, para que sin más audiencias elevara la consulta en sentido negativo, dictamen que, aceptado por el Gobierno, causaba ejecutoria y hacía imposible todo el ulterior recurso. Duro en demasía, parece cerrar la entrada al juicio a quien no es oído acerca de los motivos que se oponen a la admisión de la demanda, porque esto equivale a juzgarlo sin defensa. Justo es, pues, señalar un procedimiento brevísimo en que se dé audiencia al que pueda ser perjudicado de una manera irreparable, porque todo fallo que hace imposible el litigio produce los mismos efectos que una sentencia condenatorian.

Cuando la Audiencia niegue la admisión, quedará expedito, al que se considere agraviado, el recurso de apelación ante la Sala Tercera del Tribunal Supremo de Justicia. El fallo de esta Sala, admitiendo o rechazando la demanda, será ejecutorio (art. 24). Cuando se admita la demanda por la Audiencia, no habrá lugar a apelar, pero podrá alegarse su improcedencia como excepción perentoria, sin que esto impida ni suspenda el curso del pleito (art. 25). Queda suprimida, por lo tanto, la consulta que antes hacía el Consejo de Estado sobre la

46 Es curiosa la contradicción, en este aspecto, del preámbulo y el texto articulado. En aquél se alude a ciertos casos en que puede no ser parte el Ministerio fiscal, mientras en el último - con más precisión técnica - su intervención es obligatoria en el incidente previo, aunque no la tenga en el pleito principal. Existe otro lapsus en el artículo 23 , que indica equivocadamente el artículo $7 .^{\circ}$ como regulador del procedimiento incidental sobre la admisibilidad, contenido en el artículo $8^{\circ}$ 
admisión o denegación de admisión de las demandas y la resolución del Gobierno sobre su procedencia (art. $\mathbf{8}^{\circ}$ ).

\subsubsection{La actividad probatoria}

Otra innovación muy importante, consecuencia del propósito de garantizar al máximo los derechos legítimos de los particulares, se opera en esta fase procesal: el artículo $6 .^{\circ}$ del Decreto de 13 de octubre estableció que la proposición y realización de prueba por los litigantes se efectuaría conforme a las disposiciones de la Ley de Enjuiciamiento Civil. Sin embargo, tal criterio inicial quedó desvirtuado en el Decreto de 26 de noviembre, ya que se conservan los procedimientos contencioso-administrativos existentes, incluso en lo referente a la práctica de las diligencias de prueba o que para el esclarecimiento de los hechos sean necesarios (arts. $7 .^{\circ}$ y 20 ). Alfaro comenta que «algún tanto ligeros estuvieron los legisladores en esta disposición, al exceptuar, o mejor dicho, borrar del procedimiento todo lo tocante a las pruebas, cuando este punto cabalmente era de lo más científico a la par que práctico de cuantos extremos comprendía este procedimiento... y así lo comprendió, sin duda, el Presidente del Tribunal Supremo y los jurisconsultos que le auxiliaran en la confección de este Decreto, cuando en el artículo citado no se contentan con decir en general que la tramitación de los negocios contencioso-administrativos se sujetaban a los procedimientos vigentes hasta la fecha, sino que se recalcan diciendo, incluso, la práctica de las diligencias que para el esclarecimiento de los hechos sean necesarias" 47 . Sin embargo, parece ser que las normas reglamentarias en esta materia fueron "algún tanto alteradas... por la práctica de los tribunales ordinarios, en el sentido de la mayor solemnidad y lentitud», según nos informa Tejada de Valdosera ${ }^{48}$.

\subsubsection{La resolución definitiva}

"Desde el momento en que se llevan al Tribunal más alto de la nación las cuestiones contencioso-administrativas, no es posible conservar la consulta sobre la procedencia o improcedencia de las

47 Alfaro, op. cit., pág. 40.

48 Tejada de Valdosera, op. cit., pág. 74. 
demandas, ni las que se hacía de las sentencias definitivas». Esta declaración del preámbulo encuentra su reflejo en el texto del Decreto de 26 de noviembre. No sólo se suprime la consulta que antes hacía al Consejo de Estado sobre la admisión de las demandas y la resolución del Gobierno acerca de su procedencia (art. $8 .^{\circ}$ ), sino también la que se hacía al Gobierno respecto de las sentencias definitivas ${ }^{49}$. Éstas «se extenderán en la misma forma que las pronunciadas por las otras Salas, siempre serán fundadas, $y$, sin perjuicio de los recursos de aclaración o revisión en los casos que procedan, causarán ejecutoria y se insertarán en la Colección Legislativa (art. 10). El artículo $3 .^{\circ}$ del Decreto de 16 de octubre había establecido ya que todos los acuerdos, sentencias y resoluciones que dictaren las Salas (tanto en el Tribunal Supremo como en las Audiencias), lo serían por mayoría absoluta de votos.

\subsection{Conclusión}

El sistema implantado en 1878 no pudo consolidarse por impedirlo la coyuntura histórica. No cabe hablar de éxito o de fracaso, sino más bien de frustración. Duró tan sólo seis años, tiempo de prueba escaso, como reconocía Tejada de Valdosera ${ }^{50}$, y se derrumbó por causas ajenas a sus virtudes o pecados. No son los contemporáneos, ofuscados por sus personales condicionamientos de toda índole, ni tampoco los hombres de hoy, desde una perspectiva distinta, fuera de su tiempo, quienes han de pronunciar el veredicto definitivo sobre la reforma de 1868. Este veredicto le corresponde a la propia dinámica vital de las instituciones, convertida ya en historia. Ella nos muestra que, no obstante la opinión adversa de los juristas, otra más profunda fuerza colectiva, casi telúrica, empujó lo contencioso-administrativo hacia una irreversible judicialización, como pone de manifiesto la serena contemplación del proceso evolutivo de esta jurisdicción especial desde aquella lejana época hasta hoy.

49 Con carácter transitorio se establece que, no obstante lo dispuesto en el artículo anterior, el Gobierno resolverá sobre la procedencia de la vía contenciosa en los casos en que el Consejo hubiere elevado su informe antes del día 13 de octubre de este año (art. $9 .^{\circ}$. También el Gobierno decidirá, según las leyes anteriores, sobre los proyectos de sentencias acordadas por la Sala de lo Contencioso del Consejo de Estado, o por este Cuerpo en pleno, antes del 13 de octubre de este año (art. 10).

50 Tejada de Valdosera, op. cit., pág. 73. 
Aun cuando parece que ya en 1874 existía en la Presidencia del Gobierno un expediente, dictaminado por el Consejo de Estado, para que éste recuperara sus atribuciones contenciosas ${ }^{51}$, fue la Restauración quien realizó tal restitutio in integrum, más por una celtibérica reacción pendular respecto del régimen anterior que por auténtica convicción. El Decreto del Ministerio-Regencia de 20 de enero de 1875 devuelve al Consejo de Estado y a unas comisiones provinciales, creadas en sustitución de los antiguos consejos, la jurisdicción contencioso-administrativa con carácter retenido, si bien se trataba de una medida urgente y provisoria en un ambiente donde se reconocía la necesidad de una reforma del sistema. Diversas tentativas en tal sentido tuvieron lugar en 1879,1883 y 1886 , año este último en el que un Gobierno liberal presidido por Sagasta presentó un proyecto donde se encomendaba otra vez lo contencioso-administrativo al Tribunal Supremo y a las Audiencias territoriales, si bien el Congreso puso en su lugar un Tribunal especial y otros regionales de composición mixta, mientras que el Senado - cuerpo aún más conservador-sustituía éstos por otros provinciales y encuadraba a aquél en el Consejo de Estado, sin que por otra parte llegara a convertirse en Ley 52.

La Ley de 13 de septiembre de 1888, también en el mismo período de administración liberal, consiguió una auténtica concordia entre los partidarios de las dos posturas antagónicas, mediante el establecimiento del llamado sistema "armónico», propugnado por Santamaría de Paredes y que los demás juristas acogieron como única solución viable, dentro del espíritu transaccional del régimen canovista y favorecida también por el cansancio de una polémica que habia empezado con el siglo. Desde este momento, la jurisdicción contencioso-administrativa se ejerce ya en nombre del Rey, pero con carácter delegado, por un Tribunal contencioso-administrativo, que más adelante quedaría encuadrado en el Consejo de Estado (1894) y por Tribunales provinciales constituidos en las Audiencias. El primero se componia de un presidente y diez ministros, de los cuales tres podian serlo quienes reunieran las condiciones exigidas para Magistrado del Tribunal Supremo, con el respaldo de la inamovilidad reconocida a los miembros del Tribunal de Cuentas en 1887, que debilitó las garantías de que gozaban a este respecto en la Ley de 25 de junio de 1870, similares a las establecidas en la coetánea Ley Orgánica del Poder Judicial. Los Tribunales provinciales quedaban integrados por el Presidente de la

51 Gallostra, pág. 87; Bravo, pág. 35.

52 Santamaría de Paredes, pág. 842. 
Audiencia Territorial o Provincial, dos Magistrados de lo Civil o de lo Criminal, respectivamente, y dos Diputados provinciales letrados, vocales que se designaban anualmente por turno de antigüedad en el caso de los judiciales y por sorteo en el caso de los administrativos.

Tal sistema era una forma sutil de vestir al lobo judicial con la piel de oveja administrativa y, en definitiva, constituía un paso más en el camino de la judicialización. Esta tendencia evolucionaría en el sentido que señalaba su propia lógica intrínseca, al margen de malabarismos conceptuales, tan bien intencionados como desprovistos de arraigo en la realidad. La Ley de 5 de abril de 1904 desgajó el Tribunal de lo Contencioso del Consejo de Estado para integrarlo en el Tribunal Supremo como la tercera de sus Salas, cuya composición invirtió el planteamiento originario, pues sólo tres de sus Magistrados podrían ser de procedencia administrativa. No faltaron luego desviaciones circunstanciales, entre las que destaca el recurso de agravios (1944-1957), fenómeno de regresión al sistema de jurisdicción retenida, rechazado una vez más por la opinión pública, que jamás confió en su eficacia. Este ciclo histórico se completará en 1956 con la judicialización absoluta, templada por el necesario ingrediente de la especialización profesional, si bien en el Tribunal Supremo se conserve el reclutamiento mixto y en la configuración jurisdiccional perduren residualmente las huellas de su origen retenido.

La experiencia demuestra así que los hombres de 1868 tenían ideas muy claras y esencialmente exactas sobre el Poder judicial y lo contencioso-administrativo. La razón histórica era suya. La fugacidad del ensayo resultó engañosa y sus enemigos obtuvieron un triunfo pírrico: ganaron aquella batalla, pero perdieron la guerra. La judicialización se impuso por su arraigo en la conciencia colectiva del pueblo español, realista, crítico, nada propicio a las abstracciones, con un cervantino sentido del humor y una apasionada sed de justicia. El sistema judicial, "cuestión indígena", aspiración solamente sostenida y practicada en nuestro país y "original invento español", según Gallostra ${ }^{53}$, que observó el hecho pero no supo interpretarlo correctamente, triunfó por su adecuación a la base sociológica, sin un apoyo "científico" y huérfano de defensores incluso en el debate parlamentario de 1887, mientras consumieron muchos turnos los partidarios del modelo francés ${ }^{54}$.

53 Gallostra, págs. 19, 21 y 22.

54 SANTAMARÍA DE PAREDES: El discurso íntegro figura como apéndice al final de la obra, págs. 881-914. Cfr. sobre el sistema judicial, pág. 896. 
Estamos ahora, a principios del tercer milenio, donde nos dejó la Ley Orgánica del Poder Judicial hace un siglo. La Ley de 27 de diciembre de 1956 volvió a los orígenes, con los perfeccionamientos aconsejados por la experiencia. La reforma de 1868 se nos muestra así como una clarividente anticipación del futuro, que no arraigó entonces precisamente por adelantarse a su tiempo, pero que dejó bien plantada la semilla. Su principio rector era muy simple. Si los jueces, como hombres que son, no siempre consiguen hacer justicia, sólo ellos, como institución, deben administrarla ${ }^{55}$.

\section{EL TRIBUNAL DE CUENTAS}

\section{Características de la Ley Orgánica}

La primera Ley Orgánica del Tribunal de Cuentas, promulgada el 25 de agosto de 1851, responde a un planteamiento político muy concreto: es obra del partido "moderado" $y$, por ello, refuerza la prerrogativa del Poder ejecutivo en el nombramiento de los altos cargos del Tribunal, situado en posición subordinada, como consecuencia de su disminuida independencia y la amovilidad del personal jurisdiccional. No tiene nada de extraño que en pleno "bienio progresista" se pretendiera su modificación: con tal finalidad, la Real Orden de 3 de abril de 1855 creó una Comisión "para el único objeto de adelantar, hasta donde fuese posible, los trabajos preparatorios para llevar a cabo la organización del mismo Tribunal»; como consecuencia de lo establecido en el artículo 15 del Título VIII del proyecto de Constitución, se dictó otra Real Orden el 6 de septiembre de ese mismo año, en virtud de la cual se disolvía la anterior Comisión y se creaba una nueva «para que, con presencia de los datos y trabajos que, la suprimida Comisión, hubiere recogido y preparado, se ocupe no solamente de formular el correspondiente proyecto de Ley del Tribunal, que el Gobierno se propone someter a la aprobación de las Cortes, sino también el Reglamento orgánico por el que habrá de regirse el mismo, y de revisar y

55 No se entienda la palabra «juez» en un sentido estamental, producto de un aberrante uespiritu de cuerpo». Nada más lejos de mi pensamiento. El juez es en sustancia una persona colocada en un determinado status y que ejerce una función específica, lo cual se traduce psicológicamente en una mentalidad peculiar. La formación intelectual, la experiencia profesional y el sistema de reclutamiento son factores secundarios. 
poner en armonía con ambas cosas la Ley de Contabilidad, como complemento de la legislación en materia de tanta importancia y trascendencia para el servicio del Estadon" 56 . La vuelta al poder de los conservadores y la eliminación oficial de la ideología progresista dejó sin efecto estos propósitos, que renacieron al triunfar la "Gloriosa". El Decreto de 29 de octubre de 1869, firmado por el Regente con el refrendo de Constantino de Ardanaz, ministro de Hacienda, autoriza a éste para que presente a las Cortes Constituyentes los proyectos de Ley de organización y atribuciones del Tribunal de Cuentas del Reino y de Administración y Contabilidad del Estado.

Aprobadas ambas por las Cortes el 3 de junio de 1870, el siguiente dia 25 son promulgadas simultáneamente por el Regente (que carecía de la potestad de sancionarlas), cuya firma refrenda Laureano Figuerola, ministro de Hacienda57; la promulgación se hacía con carácter provisional y una exposición de motivos común ${ }^{58}$. Posteriormen-

56 Esta Comisión estaba compuesta de los individuos siguientes: presidente, don Antonio de los Ríos Rosas, ministro que ha sido de la Gobernación; vocales, don Joaquín María Pérez, y don Ambrosio González, presidente y fiscal del actual Tribunal; don José de la Mesa, superintendente cesante de la Isla de Cuba, y don Ignacio Olea, don Francisco de Paula Villalobos y don Ruperto Navarro Zamorano, diputados de las Cortes Constituyentes, y secretario sin voto, don Miguel Ayllón, agente fiscal de dicho Tribunal.

57 La Ley consta de 72 artículos, distribuidos en seis capítulos, y cuatro disposiciones transitorias; aparece firmada en el Palacio de las Cortes el 3 de junio por Manuel Ruiz Zorrilla, presidente; Manuel de Llano y Persi, Julián Sánchez Ruano, Francisco Javier Carratalá y Mariano Rius, diputados secretarios; el siguiente día 25 la promulga Francisco Serrano y la refrenda el ministro de Hacienda, Laureano Figuerola. El capítulo I (arts. 1-15) se refiere al carácter y organización del Tribunal de Cuentas; el II (arts. 16-22) comprende sus atribuciones; el III (arts. 2326), las atribuciones peculiares del presidente, del fiscal y del secretario; el IV (arts. 27-58) regula el examen y juicio de las cuentas; el V (arts. 59-66), los alcances y desfalcos, y el VI (arts. 67-72), la cancelación de fianzas; la primera disposición transitoria se refiere a la Comisión parlamentaria; la segunda, al traspaso de expedientes de reintegro al Ministerio de Hacienda; la tercera, a las cuentas atrasadas, que se enjuiciarán con arreglo a la Ley de Contabilidad de 1850, y la cuarta autoriza al Tribunal para publicar los reglamentos necesarios. Como podrá comprobarse, la estructura formal de la Ley coincide, en sus líneas fundamentales, con la de 25 de agosto de 1850; cfr. MendizABal Allende, Rafael: «El Tribunal de Cuentas y el nacimiento de la Administración contemporánea», en Revista de Administración Pública, . $^{\circ} 49$, enero-abril 1966, págs. 106-107.

58 El ministro de Hacienda, al presentar a las Cortes Constituyentes los proyectos de ambas Leyes, exponía sus "motivos" o directrices fundamentales, en una larga exposición, que puede resumirse mediante el análisis de sus principios. Unos son de carácter político y se encaminan, por una parte, a que "el país conozca más detalladamente la inversión de los sacrificios que se ha impuesto y el valor que 
te, un Real Decreto de 8 de noviembre de 1871, sancionado por Amadeo I y con el refrendo de don Santiago de Angulo, aprueba el Reglamento para la ejecución de aquella norma ${ }^{59}$. El propio Pleno del Tribunal elabora más adelante su propio Reglamento interior, que lleva fecha del 14 de julio de $1874^{60}$. La nueva Ley Orgánica permanecerá

representa el caudal de la Nación», y que comprenda "que no se irá en los gastos más allá de las previsiones comprendidas en la Ley"; por otra parte, se trata de limitar la acción del Gobierno y conseguir mayor eficacia: ambas finalidades justifican la vinculación del Tribunal de Cuentas a las Cortes, según establece la Constitución, así como que aquél se encargue de la fiscalización de los créditos extraordinarios, suplementos de crédito y los contratos de adquisición de fondos. Otros principios son estrictamente jurídicos: $\left.1^{\circ}\right)$ la clasificación de la contabilidad en tres ramas, legislativa, administrativa y judicial, propia de la época; $2^{\circ}$ ) la unificación de la ordenación de los pagos de la administración económica, civil y militar, la unificación y fortalecimiento de la intervención de los pagos y examen administrativo de las cuentas $y$, finalmente, el examen, juicio y fallo de éstas por el Tribunal; $\left.3 .^{\circ}\right)$ la instrumentación de tales directrices mediante la técnica legislativa de reforma y desarrollo de normas anteriores como planteamiento de unas bases que permitan una reorganización gradual y definitiva. También se alude a criterios financieros, constituidos por el propósito de conseguir que uprosperen las rentas, se aumenten los recursos, se regularicen los gastos y se llegue al establecimiento de un sistema económico completamente normal, que aleje todo peligro de perturbaciones, como aquellas que, ocasionando el aumento de nuestra Deuda, pusieron al Estado en el conflicto de no poder un día atender a sus obligaciones más sagradas".

59 El Reglamento consta de 144 artículos (casi cien menos que el de 1853), distribuidos en otros seis capítulos. El capítulo I se refiere a la organización del Tribunal y sus dependencias (arts. 1-36); el II, a las correcciones disciplinarias (arts. 37-40), el III, a las atribuciones gubernativas del Tribunal (arts. 41-56); el IV se subdivide en cuatro secciones, que comprenden las atribuciones contenciosas (arts. 57-119): Sección 1. ${ }^{a}$ del juicio de cuentas y sus recursos (arts. 57-91); Sección 2. ${ }^{a}$, del procedimiento de reintegro y sus recursos (arts. 92-110); Sección 3. ${ }^{a}$, de la cancelación de fianzas y de los recursos para obtenerla (arts. 111-115); Sección $4{ }^{a}$, del procedimiento contra ausentes cuyo domicilio se ignora y del juicio en rebeldía (arts. 116-119); el capítulo $V$ regula las relaciones del Tribunal con la Comisión de las Cortes, Ministerios, Tribunales y Centros administrativos (arts. 12()-134); y el VI contiene las disposiciones generales. Simultáneamente fue aprobado el Reglamento orgánico de Contabilidad de la Hacienda Pública e Intervención general de la Administración del Estado, al que más adelante se aludirá.

60 En uso de la autorización contenida en la disposición transitoria $4 .^{a}$ de la Ley, el Tribunal de Cuentas elaboró un Reglamento interior, aprobado por el Pleno en 14 de julio de 1874. Este Reglamento comprende 184 artículos, divididos en nueve títulos: el I, dedicado al Tribunal Pleno, su constitución, sesiones y asuntos de su competencia (arts. 1-39); el II, a la Presidencia, el presidente y sus atribuciones peculiares (arts. 40-43); el III, a las Salas, sus ministros, decanos, letrados y secretarios: celebración de las mismas $y$ despacho de los asuntos que las corresponden (arts. 44-67); el IV, a la Secretaría general, sus atribuciones y negociados 
en vigor sustancialmente hasta 1924, y ganará, como el Cid, una batalla después de su muerte, ya que rigió nuevamente desde 1930 a 1934, aun cuando durante tan largo período de vigencia sufriera alteraciones de gran trascendencia, numerosas vicisitudes y hasta eclipses parciales, como consecuencia del impacto producido por el criterio doctrinario de la Restauración.

Según Corrales, esta nueva Ley Orgánica «llega a límites de perfección que hacen que... nada tenga que envidiar a las de los demás países" 61 , juicio hiperbólico no exento de cierto fundamento. Contemplada esta norma desde una perspectiva política, incorpora con gran pureza y rigor los principios informadores del régimen democrático en el que se inserta. El Tribunal se sitúa al margen del Poder ejecutivo, con plena independencia garantizada por una rigurosa inamovilidad del personal jurisdiccional. Por otra parte, se establece una

asignados a la misma (arts. 68-104); el V, a las Secciones, sus miembros, jefes, examen y curso de las cuentas, pliegos de reparos y su contestación hasta ponerlas en estado de fallo (arts. 105-136); -el VI, a los negociados especiales de reintegro por alcances y desfalcos (arts. 137-158); el VII, a las cancelaciones de fianzas, sus trámites y recursos (arts. 159-161); el VIII, al Ministerio Fiscal (arts. 162-166); el IX, a las disposiciones generales (arts. 167-184). Existe una edición realizada en la imprenta de los señores Rozas, calle Tudescos, $n .^{\circ} 34$, principal, Madrid, 1874 , que contiene en las 62 páginas primeras el Reglamento y en las 150 siguientes una serie de formularios. Este Reglamento sustituyó al aprobado en 31 de mayo de 1860 . comprensivo de 101 artículos con 35 modelos para las actuaciones en juicio de las cuentas.

61 Corrales SÁnchez, Enrique: La institución del Tribunal de Cuentas en España y en el extranjero, Madrid, 1902, pág. 99. Una opinión coincidente casi literalmente con la ya transcrita es la de ORTIZ ARCE, David, en "Tribunal de Cuentas del Reino", Enciclopedia Jurídica Seix, t. XXX, pág. 386; García Trevijano, José Antonio, en "La Nueva Ley Orgánica del Tribunal de Cuentas", Revista de Administración Pública, n. ${ }^{\circ} 12$, septiembre-diciembre 1953, pág. 253, reproduce sustancialmente esta calificación; GonZÁLEZ CEDRón, Antonio; MÉNDEZ DE VIGO, Leoncio, y EMILIO PERAL, Florentino, en su obra Nociones generales de contabilidad pública, Madrid, 1900, pág. 806, indican sucintamente el contenido del Reglamento de 8 de noviembre de 1871 y añaden que "atiende a asimilar sus procedimientos con los civiles, aunque, sin embargo, en el de reintegro es muy deficiente, así es que se aplicaba el Reglamento de la Dirección de Contabilidad; esto por lo que se refiere a las atribuciones contenciosas. En materia de cuentas fija el significado de la censura previa y establece por primera vez la censura únican. En este último sentido se pronuncian VILLA Y LINDEMAN, Diego, y ARNAL Y FERNANDEZ, Joaquín, en su obra Ad'ministración y Contabilidad de la Hacienda Pública (Teoría y práctica), parte 1. "Técnica o Doctrinal», Madrid, 1907, pág. 744. Esto es totalmente inexacto: ni en la Ley ni en el Reglamento se menciona la "censura única", que aparece por primera vez en el Reglamento de 1893. 
estrecha vinculación con las Cortes. Quizá en el terreno abstracto de los principios resulte preferible plasmar sobre el papel la absoluta separación del Tribunal, como órgano judicial, respecto de todos los demás Poderes del Estado, pero razones prácticas aconsejaban entonces su vinculación al Legislativo. Así, las Cortes y los Tribunales ("Cortes" también), menos fuertes política y existencialmente, se apoyan frente al poder por antonomasia. Tal conexión es, además, una constante histórica y un fenómeno general en el panorama del Derecho comparado. Como muestra evidente de la interdependencia del sistema político y la regulación del Tribunal, conviene citar aquí el texto de un Decreto de 29 de mayo de 1873, donde con cierta exageración retórica se afirmaba que «existe un Tribunal encargado constitucionalmente de residenciarlas, examinando, censurando, enjuiciando y dando su fallo sobre las cuentas que tiene el deber de rendir la Administración; Tribunal cuya organización, más bien política y judicial que administrativa, no parece sino que obedeció al pensamiento preconcebido del establecimiento de la República en España, dando a aquel Alto Cuerpo orígenes y formas de carácter netamente popular» ${ }^{62}$.

Desde una perspectiva puramente técnica, la Ley Orgánica de 1870 ofrece notables aciertos, $y$, entre ellos, el de haber intentado eliminar la posición subordinada del Tribunal respecto de la Administración pública, cuyo enjuiciamiento le corresponde, intento fallido por obra de las modificaciones introducidas en 1877. Además, «judicializa" al Tribunal de Cuentas, que aparece configurado como una plena y sustantiva jurisdicción, ya que hace desaparecer - por primera vez en su trayectoria histórica - el carácter "delegado" o "retenido». Esto que en principio constituye un evidente progreso, ofrece, sin embargo, un reverso criticable, pues tan noble propósito se lleva más allá de sus limites razonables. Como consecuencia de haber quedado incorporada la jurisdicción contencioso-administrativa al Poder judicial, se creó un aparente vacío jurídico que produjo la perplejidad de los redactores de la Ley. Sin conocer probablemente la solución «doceañista», que no tuvo inconveniente alguno en conectar funcionalmente la jurisdicción contable con la ordinaria, al nivel de las Audiencias Territoria$\operatorname{les}^{63}$ y quizá también por la confusión habitual respecto de la auténti-

62 Mendizábal Allende, Rafael, "Función y esencia del Tribunal de Cuentas», Revista de Administración Pública, n. ${ }^{\circ} 46$, págs. 13-68.

63 MendizÁbal Allende, Rafael, "La crisis del "antiguo régimen" y la jurisdicción contable", Revista General de Legislación y Jurisprudencia, enero 1961, págs. 12-74. Hay edición separada (Ed. Reus), Madrid, 1961. 
ca naturaleza jurídica del Tribunal, calificado hasta entonces como un órgano de la Administración, se establece una absoluta autonomía jurisdiccional. El Tribunal de Cuentas no sólo conserva el carácter de "Supremo", sino que tal adjetivo adquiere toda su carga potencial, pues "contra sus ejecutorias no se da recurso alguno" (art. 2, L); en consecuencia, los recursos de casación y el equivalente de súplica se erradican de la jurisdicción contencioso-administrativa y se atribuyen al propio Tribunal. En el aspecto procesal y, muy especialmente, en cuanto concierne a la regulación de la responsabilidad contable, la Ley de 1870 significa una regresión respecto de la anterior, cuya precisión técnica en esta materia no ha sido superada todavía.

Finalmente, conviene señalar que la jurisdicción contable se perfila con carácter revisor de la actividad administrativa. A la Administración pública, mediante la Intervención General del Estado, luego Dirección de Contabilidad, y sus dependencias ${ }^{64}$, le corresponde el examen de las cuentas y la instrucción de los expedientes de alcance, así como la resolución «en primera instancia». Este acto administrativo es enjuiciado por el Tribunal, simultáneamente con las cuentas, en un proceso posterior. El Reglamento alude explícitamente a la confirmación o modificación del fallo de la Intervención General del Estado o del Centro de Contabilidad (art. 71), expresión que - por cierto - no utiliza la Ley (art. 44). Esta naturaleza "revisora" de la jurisdicción contable y la presencia de la $a_{z}$ Administración pública como parte, representada y defendida por el fiscal, demuestran, sin el menor margen de error, tanto la naturaleza esencialmente judicial del Tribunal de Cuentas, como su identidad sustancial con la jurisdicción contencioso-administrativa, ya que ambas tienen como objeto procesal un acto administrativo.

64 El Reglamento orgánico de Contabilidad de la Hacienda Pública e Intervención general de la Administración del Estado, aprobado por RD de 7 de noviembre de 1871, comprende 107 artículos, más una disposición transitoria, y completa el esquema esbozado por el Reglamento orgánico de la Administración económica provincial de 8 de diciembre de 1879, junto con las leyes de Contabilidad y del Tribunal de Cuentas. En la Dirección de Contabilidad se integra una Sección denominada aún tradicionalmente "Contaduría de examen de cuentas" (art. 1), cuyas atribuciones se enumeran en el art. 3 y fundamentalmente son: el examen y fallo "en primera instancia del juicio de las cuentas", la instrucción de los expedientes de reintegro por desfalco y alcances y su resolución, las relaciones con el Tribunal de Cuentas en estas materias $y$ otras varias accesorias $y$ complementarias; la Sección 2A se dividia en seis negociados (Caja y operaciones del Tesoro, rentas públicas, gastos públicos, propiedades, material y Corporaciones civiles), en la forma determinada en el art. $7 .^{\circ}$ Las normas de procedimiento se comprenden 
La Ley Orgánica de 1870 es el modelo y antecedente inmediato de la que se promulgó el 29 de julio de 1934 durante la II República española, que a su vez había sido configurada sobre el patrón del sistema político creado en 1869. No sólo transcribe literalmente muchas de sus normas, sino que, además, aparece informada por idénticos principios, con ligeras modificaciones de matiz: el fundamento ideológico es el mismo y, en consecuencia, las soluciones son también sustancialmente coincidentes. La vinculación a las Cortes, que determina ciertas peculiaridades en el régimen jurídico del personal jurisdiccional, sólo ofrece una variante en la distinta composición de la comisión parlamentaria por la estructura unicameral del poder legislativo en la Constitución de 1931, frente a la bicameral de la aprobada en 1869, que respetaba la existencia del Senado. Conviene subrayar este paralelismo entre ambos regímenes, que se refleja de modo inmediato en la organización del Tribunal de Cuentas, ya que se corresponde con la simétrica coincidencia de los criterios implantados por sistemas políticos de tendencia más conservadora, con efectos también en la jurisdicción contable (Ley Orgánica de 1851 y reforma de 1877). Así se demuestra, una vez más, la interconexión del subsuelo político y social con la forma de instrumentar la fiscalización financiera ${ }^{65}$.

\section{Delimitación jurisdiccional}

El Tribunal de Cuentas es la autoridad a quien compete el conocimiento y resolución final de las cuentas del Estado y de los demás asuntos que le están encomendados ${ }^{66}$. Su jurisdicción

en el capítulo II, que se refiere primero a las cuentas (arts. 11-57), luego a las liquidaciones de las Corporaciones civiles (arts. 58-64) y establece más adelante la tramitación de los expedientes de reintegro (arts. 65-83). Los arts. 84-90 contienen normas generales para cualquier clase de expedientes; el art. 93 enumera las atribuciones del contador de examen de cuentas, encargado de la instrucción, mientras que el art. 91 contiene las del director general, al que corresponde la resolución. La Dirección fue suprimida por RD de 29 de mayo de 1873.

65 MendizÁbal Allende, Rafael, "La Contaduria Mayor de Cuentas", Revista de Derecho Judicial, $n .^{\circ} 25$, pág. 11 , donde esta interconexión se plantea como tesis central de la investigación analítica de la trayectoria histórica del Tribunal de Cuentas.

66 El RD de 25 de marzo de 1852 establece una serie de reglas acerca de la rendición $y$ examen de las cuentas de fondos provinciales $y$ municipales, que "desde el mes de abril se pasarán al Tribunal de Cuentas del Reino las parciales de los doce meses para su ultimación». Otro, de 26 de junio de 1861, mantiene la 
"especial y privativa» alcanza, "con derogación de todo fuero", a cuantos por su empleo o por comisión temporal y especial administren, recauden o custodien efectos, caudales o pertenencias del Estado, asi como a los ordenadores, interventores y pagadores, y - finalmente - a los herederos y causahabientes de todos ellos (arts. 1 y $19 \mathrm{~L}$ ). El Tribunal ejerce sus atribuciones gubernativas, administrativas y contenciosas con entera independencia del Poder ejecutivo (art. 120 R). En consecuencia, el Pleno suspenderá el cumplimiento de cuantas órdenes reciba de cualquier Ministerio, si invaden facultades o atribuciones propias del Tribunal o de sus Salas (art. $126 \mathrm{R}$ ).

El Tribunal de Cuentas depende de la Comisión Mixta de las Cortes en cuanto al nombramiento, separación y jubilación del presidente y de los ministros, relacionándose directamente con el Congreso de los Diputados en el ejercicio de sus facultades fiscalizadoras, a quien dirigirá las Memorias así ordinarias como extraordinarias (arts. 121 y 122 R). No obstante su independencia funcional y orgánica respecto de la Administración, no se suprimen ciertas conexiones inevitables con ella: por una parte, en lo relativo al régimen del resto del personal no jurisdiccional, el Tribunal se entenderá con el Ministerio de Hacienda (art. 123 R); por otra, para el ejercicio de sus atribuciones judiciales o fiscalizadoras, el Pleno o las Salas podrán entenderse directamente con cualquier órgano

vigencia del anterior. La RO de 15 de diciembre de 1863, que desarrolla el Reglamento aprobado por otra de 10 de julio de 1861 para el régimen de las Comisiones de examen de cuentas municipales y depósitos, como consecuencia de lo dispuesto en el artículo 55 de la Ley para el Gobierno y Administración de las provincias promulgada el 25 de septiembre del mismo año, contiene algunas reglas complementarías. Otra RO de 12 de septiembre de 1864 se refiere a la intervención de las Diputaciones provinciales en los nombramientos de los oficiales de estas comisiones. Finalmente, la RO de 20 de agosto de 1872 resuelve una consulta formulada por el Tribunal de Cuentas, y aclara que éste no debe conocer de las cuentas de fondos provinciales desde el ejercicio económico 1870-1871, a partir del cual compete a las Diputaciones provinciales su examen y aprobación, salvo las excepciones del artículo 86 de la Ley orgánica provincial de 20 de agosto de 1870 . La RO de 7 de octubre de 1862 establece que ula finiquitación de las cuentas de las resultas de Espolios, después de examinadas y censuradas por la ordenación de pagos, compete al Ministerio de Gracia y Justician y no al Tribunal de Cuentas, porque tales fondos "no figuraron nunca en los presupuestos generales", y están administrados por una alta dignidad de la Iglesia y disfrutan de una jurisdicción privativa y privilegiada, ya que - por otra parte - la vigilancia del Tribunal de Cuentas se ejerce sobre todo aquello que pertenece al Estado en el orden civil y económico, pero no sobre lo puramente eclesiástico. 
administrativo, así como exigir antecedentes, datos, noticias o documentos (art. $129 \mathrm{R}$ ).

\section{EPÍLOGO: LA JUSTICIA CONSTITUCIONAL A LA VISTA}

Como coda final conviene advertir que, en esta visión panorámica, pero desde otra perspectiva, la justicia constitucional aparece en el horizonte. Es evidente que a estas alturas del siglo había llegado ya la noticia de la revisión judicial de las Leyes nacida en Estados Unidos. No sé cómo ni cuándo ni a través de quién llegó la noticia. Su exposición no tiene cabida en los libros de la época sobre el Derecho Político. No se busque en Colmeiro ni en los demás. No parece inverosímil, sin embargo, que Montero Ríos estuviera al tanto y que incluso le atrajera, pero de ahí a buscar y encontrarla en la Ley Orgánica del Poder Judicial en una hermenéutica rebuscada, hay un salto en el vacío, cuando ni siquiera estaba en la mente de los juristas de la época la impugnación directa de los reglamentos por eventual ilegalidad. Conviene retrollevarse a la época y recordar que a la sazón no se daban entonces la admiración y el mimetismo de lo norteamericano que luego fueron habituales. Aquel país se veía como lejano y extravagante, inferior intelectualmente y del que nada se podía aprender. Lo meritorio es que Tocqueville superara estos prejuicios y su complejo de superioridad europeo. Lo normal era el desconocimiento por desinterés y ni siquiera menosprecio.

En efecto, la existencia de una justicia constitucional al otro lado del Atlántico era conocida entre quienes redactaron el proyecto de Constitución de la Primera República, el año de 1873, pues en ese texto frustrado se pretendió establecer un Tribunal Supremo Federal, con tres magistrados por cada Estado de la Federación, a quien correspondería suspender los efectos de cualquier ley contraria a la Constitución dada por el Poder legislativo, mientras que el Senado tendría a su cargo, entre otras, la misión de examinar si las leyes del Congreso desconocían los derechos de la personalidad humana o de los poderes de los organismos políticos, o de las facultades de la Federación o del Código Fundamental (arts. 70, 73 y 77), y si creyera que se vulneraba alguno de estos aspectos podía también suspender la promulgación de la Ley durante tres años, transcurridos los cuales habria de ser promulgada en el acto. Sin embargo, el Poder Judicial retenia 
la competencia de declarar, en su aplicación, si la Ley era o no constitucional67. En 1983, Santamaría de Paredes menciona por primera vez en un libro español a "los autores del Federalista", al hablar de la independencia judicial.

67 Mendizábal Allende, Rafael de, "Códice con un juez sedente", Discurso de ingreso en la Real Academia de Jurisprudencia y Legislación. La Ley, Madrid, 1999, págs. 98-99.SANTAMARía De PAREDES, Curso de Derecho Político, Valencia, 1883, pág. 337. 